\title{
Stages of soil development in the coastal zone of a disappearing lake-a case study from central Poland
}

\author{
Bogusława Kruczkowska ${ }^{1}$ (D) Jerzy Jonczak ${ }^{1} \cdot$ Sandra Słowińska $^{2} \cdot$ Arkadiusz Bartczak $^{3} \cdot$ Mateusz Kramkowski $^{3}$. \\ Łukasz Uzarowicz ${ }^{1}$. Sebastian Tyszkowski ${ }^{3} \cdot$ Michał Słowiński $^{4}$
}

Received: 22 October 2020 / Accepted: 17 January 2021 / Published online: 29 January 2021

(C) The Author(s) 2021

\begin{abstract}
Purpose The aim of this study was to estimate the impact of lake disappearance, groundwater table fluctuations, and some aspects of human pressure on stages of soil cover development in the catchment of Lake Rakutowskie.

Materials and methods Research was conducted in soil chronosequence composed of eight soil profiles located in 785-m-long transect. Soils were sampled every $10 \mathrm{~cm}$. Physical and chemical properties were determined with the use of disturbed and undisturbed samples. Radiocarbon dates were obtained for the bottom part of peat in each soil profile. The mineral composition of selected soil samples was determined using the X-ray diffraction (XRD) method. Additionally, the hydrological conditions were continuously monitored from July 27, 2013 to September 23, 2014.

Results and discussion An increased rate of shallow lakes overgrowth and final disappearance is a commonly observed process in the European lowlands. This paper presents and discusses the influence of changes in the range of the Lake Rakutowskie wetlands complex (central Poland) and water level fluctuations on soil cover transformation in the immediate vicinity of the lake. Five major phases of soil cover development (from Subaquatic Histosols (Limnic) to Hypereutric Regosol (Drainic, Humic)) were hypothetically reconstructed based on detailed studies of soil physical and chemical properties, mineral composition, water level fluctuations, and radiocarbon dating. The degree of peat decomposition in the studied profiles increased with the distance from the contemporary lake surface. Along with the progressive dehydration and mineralization of organic soils, their physical and chemical properties deteriorated, which is visible, e.g., in soil structure, and mineral and chemical composition (especially TOC and TN). Obtained radiocarbon ages of selected samples indicate that the oldest peat layers developed about 5856 cal BCE $\left(6970 \pm 70{ }^{14} \mathrm{C} \mathrm{BP}\right)$, while the youngest were deposited about $1074 \mathrm{cal} \mathrm{CE}\left(980 \pm 40{ }^{14} \mathrm{C} \mathrm{BP}\right)-1573 \mathrm{cal} \mathrm{CE}\left(300 \pm 35{ }^{14} \mathrm{C} \mathrm{BP}\right)$. Hydrological studies indicate a progressive process of lake disappearance.

Conclusions The process of soil cover transforming of the studied area takes place relatively quick, mainly recently due to the influence of human activity. Based on these results, it can be predicted that the lake will most likely disappear in a relatively short time, and the soil cover will be entirely in the fifth phase (P5) of evolution.
\end{abstract}

Keywords Lake disappearance $\cdot$ Shallow lakes $\cdot$ Histosols $\cdot$ Mineral composition $\cdot$ European lowlands

Responsible editor: Claudio Bini

Bogusława Kruczkowska

boguslawa_kruczkowska@sggw.edu.pl

1 Department of Soil Science, Institute of Agriculture, Warsaw University of Life Sciences-SGGW, Nowoursynowska Str. 159, building no. 37, 02-776 Warsaw, Poland

2 Department of Geoecology and Climatology, Institute of Geography and Spatial Organization, Polish Academy of Sciences, Twarda Str. 51/55, 00-818 Warsaw, Poland
3 Department of Environmental Resources and Geohazards, Institute of Geography and Spatial Organization, Polish Academy of Sciences, Kopernika Str. 9, 87-100 Torun, Poland

4 Past Landscape Dynamics Laboratory, Institute of Geography and Spatial Organization, Polish Academy of Sciences, Twarda Str. 51/ 55, 00-818 Warsaw, Poland 


\section{Introduction}

The origin of most lakes occurring in northern and central Poland is associated with the ice sheet activity which occupied this area during the Pleistocene period. The results of paleolake reconstruction of Polish lakelands indicate that about $67.4 \%$ of postglacial lake surface has already disappeared (Kalinowska 1961), with $11.2 \%$ of this occurring in the last 70 years (Choiński et al. 2016). There are an increasing number of sites that either are or will be in the near future in the transition phase.

The process of lake disappearance worldwide is a stage of landscape evolution and its intensity depends on many environmental and anthropogenic factors. However, in the case of shallow lakes, the impact of human activity, mainly agriculture, can be the major factor determining their existence. The stages of lake basin evolution also depend on morphometric parameters and water characteristics. Shallow lakes are highly unstable ecosystems, sensitive to climate changes, in particular the climatic water balance (Scheffer 2004). Lake disappearance can be treated as a sum of two factors: surface area declines and shallowing followed by the lake succession process (Birks and Birks 1980; Cohen 2003; Rydin and Jeglum 2006). In addition to natural factors, the impact of anthropogenic processes, especially over the past decades, plays a significant role in lake area reduction (Scheffer 2004; Rydin and Jeglum 2006; Choiński et al. 2011; Markiewicz et al. 2017). The first phase of lake disappearance were climate changes which occurred in the Late Glacial and Holocene and caused lake condition modifications which had an impact on water level and thereby on sediment deposition. Global warming, which in recent decades has greatly accelerated, has a very large impact on the functioning of ecosystems. Climate projections for Poland foresee warming in all seasons and changes in the distribution and quantity of precipitation (Szwed 2015). Analyses of climatic water balance (the difference between precipitation $\mathrm{P}$ and evapotranspiration E) conducted by Bartczak et al. (2019) for the investigated area showed a negative trend for the years 1967-2015. The projected further decrease in the summer climatic water balance (Szwed et al. 2010) may adversely affect shallow lake ecosystems, such as Lake Rakutowskie, causing increased vegetation overgrowth and transformation into wetland. The succession of wetland vegetation in this area, in combination with an oxygen-poor water environment, leads to accumulation of poorly decomposed plant remains and peat formation, which is the last stage of lake functioning (Tobolski 2000; Succow and Joosten 2001; Rydin and Jeglum 2006).

Peatland characteristics are mainly determined by plant cover and the geomorphological and hydrological situation and are modified by climatic conditions (Charman 2002). Hydroclimatic instability most often leads to a lowering of the groundwater table (Słowińska et al. 2010; Lamentowicz et al. 2016; Samson et al. 2018), which influences changes in acrotelm processes (Morris et al. 2011; Jassey et al. 2013; Marcisz et al. 2014; Reczuga et al. 2018). Rivers, lakes, and peatlands are also susceptible to agricultural land use and catchment deforestation (Marcisz et al. 2015; HernandezAlmeida et al. 2016; Kruczkowska 2016; Ott et al. 2017; Poraj-Górska et al. 2017). Most water bodies and adjacent areas are subject to drainage, which results in water level lowering, the uncovering of lacustrine sediments, and soil formation (Gonet et al. 2010; Mendyk et al. 2016) often with the participation of peat-forming vegetation. However, peat undergoes a mineralization process as a result of dehydration, which in turn leads to its degradation. All processes (natural and anthropogenic) leave a trace in Histosols, which can be treated as archives of natural peatland development, human activity, and the history of the catchment environment (Shotyk et al. 1998). The issue of organic soil evolution as a result of the impact of water lowering or anthropogenic processes has been widely studied (e.g., Renger et al. 2002; Pawluczuk and Gotkiewicz 2003; Becher et al. 2013; Długosz et al. 2018; Bogacz et al. 2019). However, reconstructions of soil development stages on partially or totally drained areas, including changes in soil typology, are relatively rarely represented in literature. Moreover, the majority of such studies are focused on physical and chemical property transformation as an effect of drainage, while there is no information about the mineral composition of Histosols and/or murshic soils that develop in coastal zones of disappearing lakes.

The aim of this study was to estimate the impact of lake disappearance, groundwater table fluctuations, and some aspects of human pressure on soil formation, morphology, and various properties in the catchment of Lake Rakutowskie. This lake is located in central Poland where precipitation deficit often occurs. The lake ecosystem is in a transitional phase as a result of vegetation overgrowth (Kramkowski et al. 2014) and is a good area for studies of pedogenesis in terrains adjacent to disappearing lakes.

\section{Materials and methods}

\subsection{Study area}

Lake Rakutowskie is located in the wetlands complex in the immediate neighborhood of the Great PolandKuyavian Lake District (Fig. 1), where a rapid decrease in the lake area in Poland has been observed from the 1920s (Choiński et al. 2011). It is a specific reservoir with a large and shallow lake basin with an average depth of 1 $\mathrm{m}$, where the surface area has decreased by two-thirds over the last century (documented range of the lake was 329.3 ha in 1930 and 101.8 ha in 2009) (Kramkowski et al. 2014; Bartczak et al. 2019). Now, Lake 
Fig. 1 Location of the study area. a Poland in comparison with Europe, b Central and northern part of Poland, $\mathbf{c}$ Lake Rakutowskie in neighborhood of the Great Poland-Kuyavian Lake District

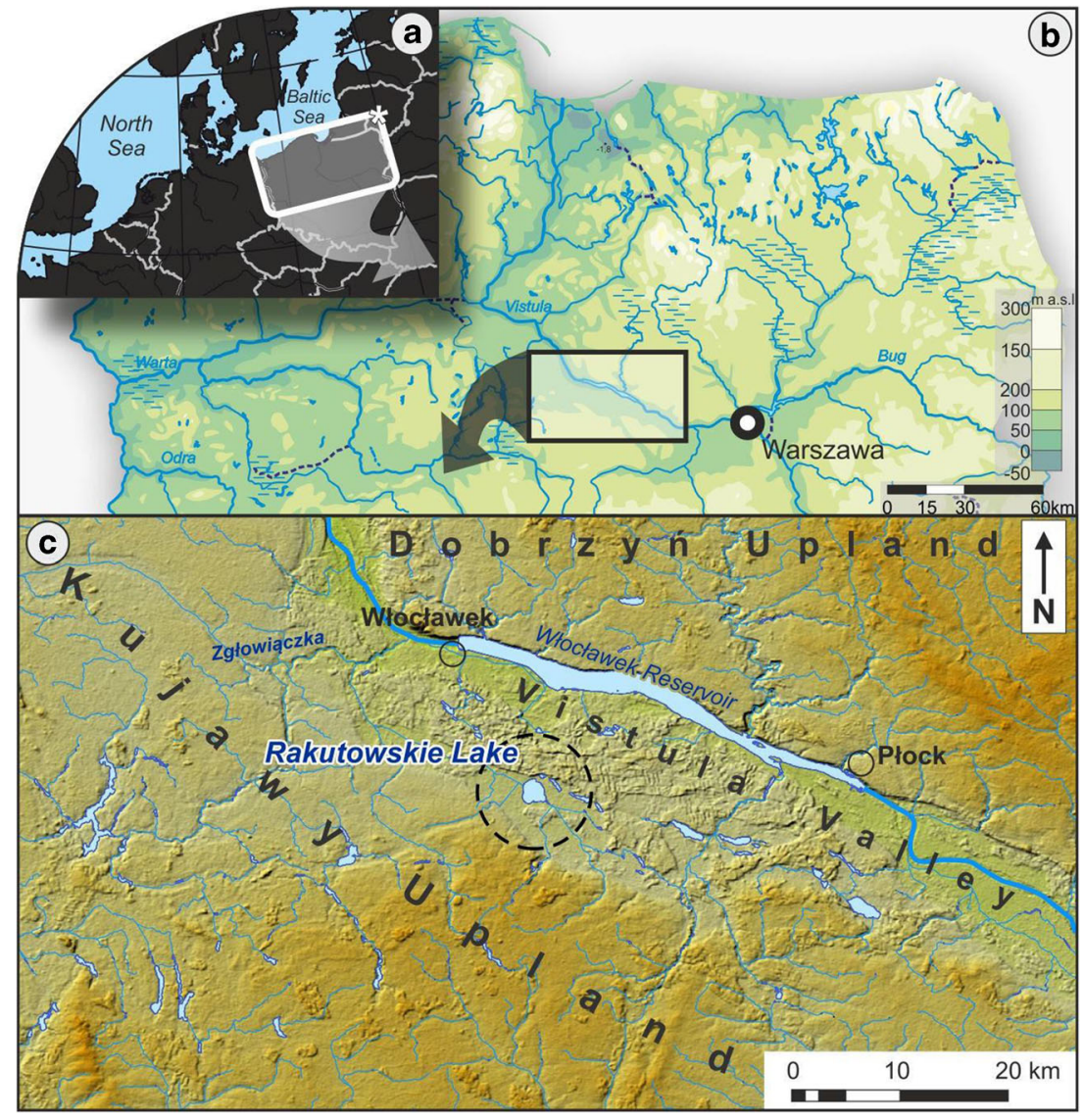

Rakutowskie is a eutrophic lake with a maximum depth of about $2.5 \mathrm{~m}$ and long, gentle slopes located within a valley in the southern part of the Płock basin (central Poland) within a young glacial landscape. The study area is a remnant of a past extensive paleolake developed during the Vistulian Glaciation (Glazik 1978). The lake is located within the largest complex of wetland ecosystems in the Gostynin Lake District and surrounded by flooded magnocaricetum grasslands and extensive biogenic plains with 2-m deep peat cover (Kramkowski et al. 2014). Quaternary sediments in the Płock basin are represented by a 35-40 m thick sandy-gravelly fluvioglacial series locally separated by marginal clayey mursh (Baraniecka 1993; Roman 2011; Kramkowski et al. 2014), which was remodeled aeolian during Late Glacial (Kruczkowska et al. 2020; Manikowska, 1982; Manikowska 1991).

The current shoreline of the lake is covered with rushes, predominantly Phragmites australis, Typha latifolia, and Schoenoplectus lacustris. Almost the whole lake bottom is covered with Chara sp. and in its bays Nuphar lutea and Nymphaea alba L. occur. In the rushes zone, the protected species Cladium mariscus has also been encountered. To the south Lake Rakutowskie is bordered with wet alder forest, while Fraxino-Alnetum and Ficario-Ulmetum minoris forests also occur. In the immediate vicinity of the lake, there are also small areas of crop fields that are extensively used for agricultural purposes due to the poor quality of the soils (Kramkowski et al. 2014).

The average sum of annual precipitation (1967-2015) within the Płock basin and surrounding areas measured at three meteorological stations (Baruchowo, Brześć Kujawski, Duninów) was $523 \mathrm{~mm}$, which is lower than average for Poland (about $600 \mathrm{~mm}$ ) (Bartczak 2007; Bartczak et al. 2019). The study area is located within the rain shadow (e.g., latitudinal zone of low precipitation $(<550 \mathrm{~mm})$ ) which extends from the eastern part of Poland through the center to the western borders of the country.

Water level fluctuations are controlled by natural factors, mainly precipitation and evapotranspiration, and human activity. Intensified deforestation, primarily adaptation of forest areas for agricultural purposes, is the major factor that affected the contemporary range of Lake Rakutowskie.

The percentage of arable lands in the vicinity of Lake Rakutowskie is small. The immediate vicinity of the lake is covered with hay meadows and pastures. The northern part of Lake Rakutowskie is covered with forest.

\subsection{Hydroclimatic monitoring}

The hydrological conditions were continuously monitored by the authors from July 27, 2013 to September 23, 2014. In 
order to record groundwater level fluctuations, we installed three PVC wells along the hydrological gradient within the peatland (from dry to wet sites) and one in the lake (Fig. 2). Each of these was equipped with a Leveloggers Junior Edge (Solinst Canada Ltd.). Water levels were measured every $3 \mathrm{~h}$, and they were compensated using atmospheric pressure and averaged to daily values. Meteorological records for the years 1967-2014 were derived from regional meteorological stations of the Institute of Meteorology and Water Management (Baruchowo station - precipitation, Płock - air temperature, and humidity), both of which were representative for the research area. We used standardized anomalies of monthly average air temperature, sum of precipitation, and climatic water balance from long-term (1967-2014) monthly averages. Thermal conditions were classified using the methodology proposed by Lorenc (1994) and precipitation and climatic water balance using the Guttman (1999) classification.

\subsection{Soil sampling and analysis}

Eight soil profiles were analyzed along a 785-m-long transect constituting the chronosequence of soils crossing varied plant communities comprising ecotone cover edge of willow bushes through a young alder forest to an old alder forest (Fig. 2).

The distance of the first profile from the contemporary lake surface was $1200 \mathrm{~m}$, while distances between each soil profile were $65 \mathrm{~m}$ ( 1 to 2 ), $160 \mathrm{~m}$ ( 2 to 3 ), $120 \mathrm{~m}$ (3 to 4 ), $100 \mathrm{~m}$ (4 to 5), $110 \mathrm{~m}$ (5 to 6$), 130 \mathrm{~m}$ (6 to 7 ), and $100 \mathrm{~m}$ (7 to 8 ). The profiles were located on a relatively flat terrain, and the height difference between the highest and lowest point was $0.8 \mathrm{~m}$ (altitude in $\mathrm{m}$ a.s.l.: profile $1-72.25,2-72.20,3-72.35$, $4-72.50,5-72.70,6-72.85,7-73.05,8-73.00)$. The studied soil profiles were characterized by increasing degrees of soil organic material transformation resulting from lake drainage. The soils were described and classified according to the WRB soil system (FAO 2006; IUSS Working Group WRB 2015) and sampled every $10 \mathrm{~cm}$. Two samples of undisturbed structure were collected from each layer/horizon using $100 \mathrm{~cm}^{3}$ steel rings to determine physical characteristics of the soils, including bulk density and porosity. Moreover, one disturbed soil sample was taken from each horizon/layer to analyze chemical properties. The peat type and decomposition degree were determined in the field using a 3-point scale (R1-R3) according to Okruszko (1976a) and Myślińska (2001). Bulk density, total porosity, and actual moisture content were analyzed using undisturbed samples with the dryingweight method. Disturbed samples were dried at $40{ }^{\circ} \mathrm{C}$ and milled into powder. The following properties were determined from these samples: loss on ignition at $550{ }^{\circ} \mathrm{C}, \mathrm{pH}$ potentiometrically in a suspension with water in a soil:water ratio of 1:2.5 (pH-meter Elmetron CPC-401), the content of carbonates according to Scheibler's volumetric method, the content of total organic carbon (TOC) with the Alten method (Dziadowiec and Gonet 1999), and total nitrogen (TN) with the Kjeldahl method (Van Reeuwijk 2002). Samples were digested in a mixture of $40 \% \mathrm{HF}$ and $60 \% \mathrm{HClO}_{4}$, and the total content of phosphorus in solution was analyzed using the molybdenum-blue method, whereas contents of potassium,
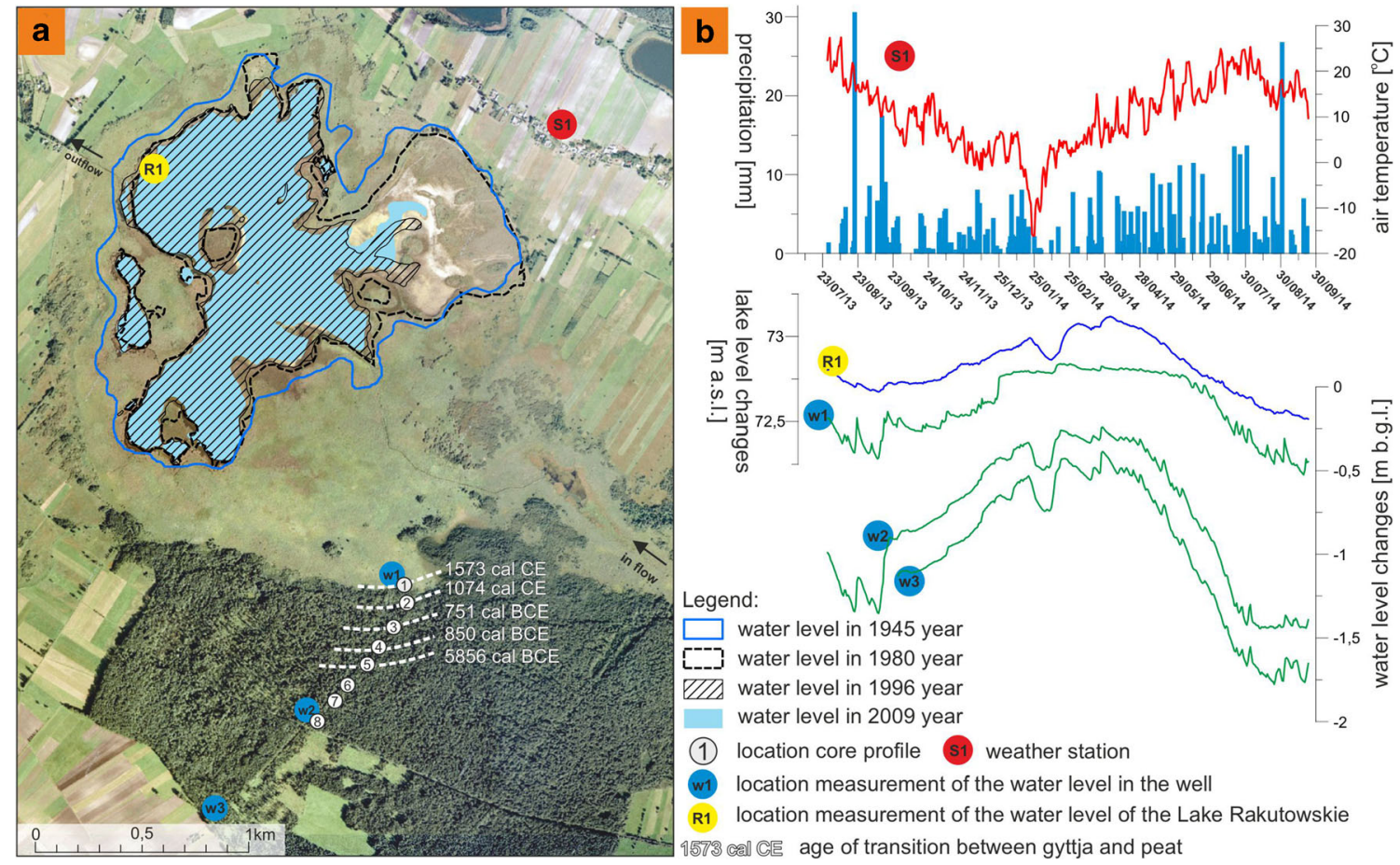

Fig. 2 The study area. a Soil profiles location. b Climatic conditions and Lake Rakutowskie water level changes 
calcium, magnesium, iron, chromium, copper, manganese, nickel, lead, and zinc were determined using flame atomic absorption spectrometry (Perkin Elmer AAS 2100).

The mineral composition of soil samples was determined using the X-ray diffraction (XRD) method. Samples were dried at $40{ }^{\circ} \mathrm{C}$ and ground into powder. The powders were analyzed by means of a Bruker AXS D5005 diffractometer equipped with a KRISTALLOFLEX® 760 X-ray generator, a vertical goniometer, 1-mm divergence slit, 2-mm anti scatter slit, 0.6-mm detector slit, and a graphite diffracted-beam monochromator. $\mathrm{CoK} \alpha$ radiation was used with the applied voltage of $40 \mathrm{kV}$ and $30 \mathrm{~mA}$ current. Random amounts of the ground materials were scanned at a counting time of $2 \mathrm{~s}$ per $0.01^{\circ}$ step from 3 to $70^{\circ} 2 \theta$.

\subsection{Radiocarbon dating}

Radiocarbon dates were obtained for the bottom part of peat in each soil profile. Dating was performed in the Laboratory of Absolute Dating, Cianowice. Samples for radiocarbon dates were taken from transition between lake sediment and peat deposits. Conventional dates were calibrated using OxCal 4.2.3 software (Bronk Ramsey and Lee 2013) and the IntCal13 calibration curve (Reimer et al. 2013). In this paper, dates are also presented in calibrated years $\mathrm{CE} / \mathrm{BCE}$.

\section{Results}

\subsection{Hydroclimatic characteristics of the Rakutowskie wetlands complex in 2013-2014}

Most of the months in the investigated period July 2013September 2014 were characterized by normal air temperature fluctuations relative to long-term averages (1967-2004) (Fig. 2). However, March and July 2014 were very warm, and November-December 2013 and April 2014 were warm, which caused the hydrological year 2014 to be classified as very warm. Based on classification with the standardized precipitation index (SPI) by Guttman (1999), the hydrological year 2013 was neutral and 2014 was moderately dry. The same situation was noted for climatic water balance.

Groundwater level fluctuations at all locations were controlled by seasonal changes in hydrometeorological conditions (precipitation and evapotranspiration), with the highest levels noted during the winter season and lowest in the summer. The wettest place with the most stable water conditions was in location w1. Median groundwater level in this location in the period September 27, 2013-September 23, 2014 (when groundwater level was recorded at all sites) was $3 \mathrm{~cm}$, and from the end of December 2013 until mid-June 2014 water stagnated about $10 \mathrm{~cm}$ above the ground. The groundwater level decreased with increasing distance from the lake. At location w2, median groundwater level was $62 \mathrm{~cm}$, and at w3, it was $90 \mathrm{~cm}$ below the surface. During the summer months in 2014, groundwater level dropped to $144 \mathrm{~cm}$ at location w2 and $178 \mathrm{~cm}$ at location w3. At location w1, it was $52 \mathrm{~cm}$ below the surface.

\subsection{Radiocarbon age of the soils}

From profile 1, the transition zone between the gyttja and peat was dated to approximately $1,573 \mathrm{cal}$. $\mathrm{CE}$, then through profiles 2, 3, and 4 the transitional age was determined as follows: 1,074 cal. CE, 751 cal. BCE, and 850 cal. BCE. The last documented phase of the Lake Rakutowskie overgrowth was dated to about 5,856 cal. BCE (profile 5). Radiocarbon ages of organic material from profiles 6-8 were rejuvenated and thus rejected due to the overly small thickness of topsoil which did not exceed $20 \mathrm{~cm}$, its total transformation into mursh, and the numerous roots of live vegetation which caused the sample to be contaminated (Table 1).

\subsection{Morphology and typology of the soils}

The immediate vicinity of Lake Rakutowskie, which was part of the former lake bottom, was mainly covered with soils developed from organic materials (peat and/or mursh) in the topsoil and lacustrine sediments (gyttja and/or lacustrine chalk) occurred at different depths in the subsoil (Fig. 3). The characteristics of the investigated sediments changed from being biogenic deposits consisting of detritus calcareous gyttja, detritus gyttja, and lacustrine chalk on the bottom to being alder swamp forest peat and reed peat in the upper part. Among the eight soil profiles, five soil reference groups were distinguished in the studied transect: Hypereutric Hemic Histosol (profiles 2 and 3), Hypereutric Hemic Histosol (Limnic) (profile 1), Hypereutric Sapric Histosol (Drainic, Limnic) (profiles 4 and 5), and Hypereutric Regosol (Drainic, Humic) (profiles 6-8) (IUSS Working Group WRB 2015). The soil morphology of each profile is presented in Fig. 3. Additionally, lake sediments which were permanently submerged by water not deeper than $200 \mathrm{~cm}$ were hypothetically classified as Subaquatic Histosols (Limnic) and Subaquatic Histosols.

\subsection{Physical properties}

Groundwater level lowered and soil moisture decreased with the distance from the lake, which reflects the percentage of water-filled pore space (Table 2). Peats in the studied soils can be classified as moderately and significantly decomposed (Table 2).

The percentage of organic soil substrates in the morphology of profiles 1-3 varied from 40 to $100 \%$, while in profiles 48 , this ranged from 20 to a maximum of $40 \%$. Additionally, 
Table 1 Radiocarbon age of peat samples from the boundary of lacustrine sediments and peat layer

\begin{tabular}{lllll}
\hline Soil profile & Depth $(\mathrm{cm})$ & Laboratory code & ${ }^{14} \mathrm{C}$ date $\left[{ }^{14} \mathrm{C} \mathrm{BP}\right]$ & Calibrated age mean (cal. CE/BCE) \\
\hline 1 & 30 & MKL-3283 & $300 \pm 35$ & $1573 \mathrm{cal} \mathrm{CE}$ \\
2 & 40 & MKL-3284 & $980 \pm 40$ & $1074 \mathrm{cal} \mathrm{CE}$ \\
3 & 140 & MKL-3285 & $2600 \pm 50$ & $751 \mathrm{cal} \mathrm{BCE}$ \\
4 & 40 & MKL-3286 & $2690 \pm 35$ & $850 \mathrm{cal} \mathrm{BCE}$ \\
5 & 40 & MKL-3287 & $6970 \pm 70$ & $5856 \mathrm{cal} \mathrm{BCE}$ \\
\hline
\end{tabular}

the percentage of organic horizons with a low degree of decomposition (R1 and R2) decreased with the distance from the lake, and this also coincided with a decrease in the thickness of organic horizons. Different degree of organic material decomposition in profiles 1 and 5 depends on distance from the lake, despite of morphological similarity of these two soils. The soils with the most decomposed peat mass (profiles 4 to 8 ), with an R3 degree of decomposition in the whole profile or with features of peat mineralization, were located at the furthest distance from the lake (Fig. 3). In these profiles, peat layers were totally or almost totally transformed into mursh with a mineral fraction content of about $30 \%$. For comparison, in profiles 1 and 2, the mineral fraction content in topsoil did not exceed $22 \%$. In the first three profiles (1-3), peat decomposition was also observed; however, significant transformations (R3 degree of peat decomposition) occurred, maximally to a depth of $30 \mathrm{~cm}$.

Transformation of organic material due to hydrological changes is reflected in soil bulk density and porosity (Table 2). Organic material from profiles 1 to 5 was still classified as peat, however, with a different degree of decomposition. In profiles 1 to 3, a decrease in bulk density with depth was observed, in contrast to the other profiles. An opposite trend occurred in the case of total porosity. A boundary between moderately and significantly transformed soils can be set between profiles 3 and 4, where there was a noticeable change in the soil physical properties (Table 2). The bulk density of superficial $\mathrm{H}$ horizons ranged from 0.21 to $0.24 \mathrm{~g}$. $\mathrm{cm}^{-3}$ in profiles with hemic material (He horizons), $0.35 \mathrm{~g}$. $\mathrm{cm}^{-3}$ in sapric material (Ha horizons) to $0.37-0.47 \mathrm{~g} \cdot \mathrm{cm}^{-3}$ in Hypereutric Regosol (Drainic, Humic ) profiles. The average percentage of the mineral fraction in surface $\mathrm{H}$ horizons is closely related to the degree of peat mineralization and ranges from $22.9 \%$ in profiles $1-3$ to $30.7 \%$ in the most transformed profiles (4-8).

\subsection{Chemical properties}

The peat materials in the investigated soils had slightly acidic to alkaline reactions ( $\mathrm{pH}$ from 6.2 to 7.6). Lacustrine sediments were characterized by similar $\mathrm{pH}$ values (from 5.9 to 8.1). However, in profiles 1 to 3 , differences in soil $\mathrm{pH}$ between the topsoil and the subsoil were relatively aligned. Clear

Fig. 3 Morphology of the studied soil profiles

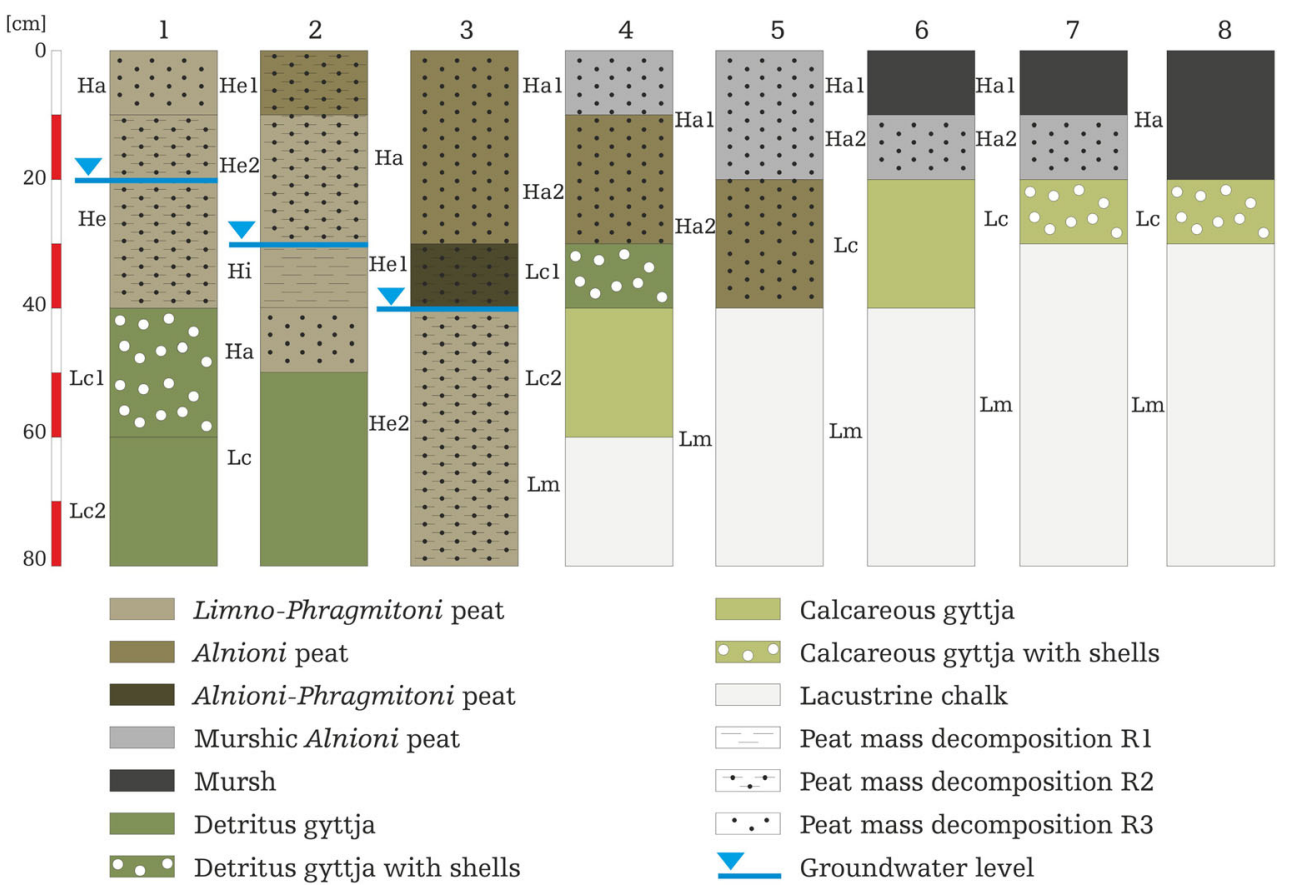


Table 2 Physical and chemical properties of the investigated soils

\begin{tabular}{|c|c|c|c|c|c|c|c|c|c|c|}
\hline Profile & Depth & $\begin{array}{l}\text { Soil } \\
\text { horizon }\end{array}$ & $\begin{array}{l}\text { Degree of peat } \\
\text { decomposition }\end{array}$ & $\begin{array}{l}\text { Water } \\
\text { ratio }\end{array}$ & $\begin{array}{l}\text { Bulk } \\
\text { density }\end{array}$ & $\begin{array}{l}\text { Total } \\
\text { porosity }\end{array}$ & $\begin{array}{l}\text { Water-filled pore } \\
\text { space }\end{array}$ & $\begin{array}{l}\text { Content of } \\
\mathrm{CaCO}_{3}\end{array}$ & $\begin{array}{l}\text { Mineral } \\
\text { fraction }\end{array}$ & $\begin{array}{l}\mathrm{pH} \\
\mathrm{H}_{2} \mathrm{O}\end{array}$ \\
\hline & $(\mathrm{cm})$ & & & $(\mathrm{v} / \mathrm{v} \%)$ & $\left(\mathrm{g} \cdot \mathrm{cm}^{-3}\right)$ & $(\%)$ & $(\%)$ & $(\%)$ & $(\%)$ & \\
\hline \multirow[t]{9}{*}{1} & \multicolumn{10}{|c|}{ Hypereutric Hemic Histosol (Limnic) } \\
\hline & $0-10$ & $\mathrm{Ha}$ & R3 & 73.7 & 0.21 & 91.0 & 81.0 & 18.7 & 20.6 & 7.5 \\
\hline & $10-20$ & $\mathrm{He}$ & $\mathrm{R} 2$ & 71.9 & 0.17 & 91.7 & 78.5 & 17.3 & 18.0 & 7.3 \\
\hline & $20-30$ & & $\mathrm{R} 2$ & 95.6 & 0.10 & 95.6 & 100.0 & 5.2 & 14.4 & 6.8 \\
\hline & $30-40$ & & $\mathrm{R} 2$ & 95.2 & 0.09 & 95.2 & 100.0 & 12.0 & 11.8 & 7.0 \\
\hline & $40-50$ & Lc1 & & 94.7 & 0.14 & 94.7 & 100.0 & 35.2 & 13.1 & 7.4 \\
\hline & $50-60$ & & & 90.6 & 0.17 & 90.6 & 100.0 & 46.9 & 14.4 & 7.6 \\
\hline & $60-70$ & Lc2 & & 91.3 & 0.11 & 91.3 & 100.0 & 5.5 & 15.6 & 7.1 \\
\hline & $70-80$ & & & 95.8 & 0.07 & 95.8 & 100.0 & 1.4 & 13.9 & 6.7 \\
\hline \multirow[t]{9}{*}{2} & \multicolumn{10}{|c|}{ Hypereutric Hemic Histosol } \\
\hline & $0-10$ & $\mathrm{He} 1$ & $\mathrm{R} 2$ & 76.7 & 0.22 & 88.1 & 87.1 & 6.1 & 21.6 & 6.9 \\
\hline & $10-20$ & $\mathrm{He} 2$ & $\mathrm{R} 2$ & 78.9 & 0.17 & 91.1 & 86.7 & 4.0 & 19.6 & 6.8 \\
\hline & $20-30$ & & $\mathrm{R} 2$ & 75.7 & 0.17 & 91.4 & 82.8 & 0.0 & 18.8 & 6.7 \\
\hline & $30-40$ & $\mathrm{Hi}$ & $\mathrm{R} 1$ & 93.6 & 0.12 & 93.6 & 100.0 & 0.0 & 12.7 & 6.4 \\
\hline & $40-50$ & $\mathrm{Ha}$ & $\mathrm{R} 2$ & 94.7 & 0.11 & 94.7 & 100.0 & 0.0 & 11.2 & 6.2 \\
\hline & $50-60$ & $\mathrm{Lc}$ & & 93.2 & 0.12 & 93.2 & 100.0 & 0.0 & 11.3 & 5.9 \\
\hline & $60-70$ & & & 94.3 & 0.12 & 94.3 & 100.0 & 0.0 & 13.0 & 6.4 \\
\hline & $70-80$ & & & 93.0 & 0.09 & 93.0 & 100.0 & 3.3 & 13.0 & 6.7 \\
\hline \multirow[t]{9}{*}{3} & \multicolumn{10}{|c|}{ Hypereutric Hemic Histosol } \\
\hline & $0-10$ & На & R3 & 78.6 & 0.24 & 87.7 & 89.6 & 0.0 & 26.5 & 6.8 \\
\hline & $10-20$ & & R3 & 74.3 & 0.25 & 84.8 & 87.6 & 0.0 & 24.0 & 6.8 \\
\hline & $20-30$ & & $\mathrm{R} 3$ & 76.9 & 0.20 & 88.7 & 86.7 & 0.0 & 20.2 & 6.8 \\
\hline & $30-40$ & He1 & $\mathrm{R} 2$ & 81.7 & 0.18 & 90.9 & 89.8 & 0.0 & 17.2 & 6.7 \\
\hline & $40-50$ & $\mathrm{He} 2$ & $\mathrm{R} 2$ & 91.2 & 0.17 & 91.2 & 100.0 & 0.0 & 16.2 & 6.7 \\
\hline & $50-60$ & & $\mathrm{R} 2$ & 91.1 & 0.15 & 91.1 & 100.0 & 0.0 & 14.8 & 6.6 \\
\hline & $60-70$ & & $\mathrm{R} 2$ & 91.4 & 0.14 & 91.4 & 100.0 & 0.0 & 16.0 & 6.7 \\
\hline & $70-80$ & & $\mathrm{R} 2$ & 88.1 & 0.17 & 88.1 & 100.0 & 0.0 & 16.2 & 6.5 \\
\hline \multirow[t]{9}{*}{4} & \multicolumn{10}{|c|}{ Hypereutric Sapric Histosol (Drainic, Limnic) } \\
\hline & $0-10$ & Ha1 & R3 & 66.1 & 0.35 & 81.6 & 81.1 & 6.0 & 28.1 & 7.3 \\
\hline & $10-20$ & $\mathrm{Ha} 2$ & $\mathrm{R} 3$ & 67.4 & 0.41 & 82.0 & 82.2 & 32.8 & 22.7 & 7.5 \\
\hline & $20-30$ & & R3 & 70.6 & 0.35 & 85.1 & 82.9 & 25.4 & 20.6 & 7.5 \\
\hline & $30-40$ & Lc1 & & 73.8 & 0.26 & 87.4 & 84.4 & 36.2 & 13.9 & 7.6 \\
\hline & $40-50$ & Lc2 & & 67.3 & 0.34 & 85.8 & 78.4 & 53.5 & 12.9 & 7.8 \\
\hline & $50-60$ & & & 72.3 & 0.41 & 84.1 & 86.0 & 73.3 & 7.7 & 8.0 \\
\hline & $60-70$ & $\mathrm{Lm}$ & & 75.0 & 0.42 & 86.6 & 86.5 & 83.6 & 5.1 & 8.0 \\
\hline & $70-80$ & & & 79.7 & 0.40 & 87.2 & 91.5 & 80.4 & 7.4 & 7.8 \\
\hline \multirow[t]{9}{*}{5} & \multicolumn{10}{|c|}{ Hypereutric Sapric Histosol (Drainic, Limnic) } \\
\hline & $0-10$ & Ha1 & $\mathrm{R} 3$ & 69.5 & 0.35 & 81.5 & 85.3 & 0.0 & 27.4 & 6.7 \\
\hline & $10-20$ & & R3 & 69.8 & 0.38 & 83.1 & 84.0 & 4.1 & 33.0 & 7.4 \\
\hline & $20-30$ & $\mathrm{Ha} 2$ & $\mathrm{R} 3$ & 74.8 & 0.25 & 87.7 & 85.3 & 1.0 & 25.8 & 7.1 \\
\hline & $30-40$ & & $\mathrm{R} 3$ & 66.4 & 0.39 & 82.3 & 80.7 & 0.7 & 17.3 & 7.2 \\
\hline & $40-50$ & $\mathrm{Lm}$ & & 69.0 & 0.55 & 81.3 & 84.9 & 85.0 & 5.7 & 8.0 \\
\hline & $50-60$ & & & 71.0 & 0.54 & 80.8 & 87.8 & 84.2 & 7.3 & 8.0 \\
\hline & $60-70$ & & & 70.1 & 0.60 & 77.9 & 89.9 & 84.2 & 9.5 & 8.0 \\
\hline & $70-80$ & & & 70.1 & 0.57 & 76.9 & 91.2 & 85.3 & 8.0 & 8.1 \\
\hline \multirow[t]{2}{*}{6} & \multicolumn{10}{|c|}{ Hypereutric Regosol (Drainic, Humic) } \\
\hline & $0-10$ & Ha1 & & 64.4 & 0.45 & 75.0 & 85.9 & 0.0 & 31.7 & 7.0 \\
\hline
\end{tabular}


Table 2 (continued)

\begin{tabular}{|c|c|c|c|c|c|c|c|c|c|c|}
\hline Profile & Depth & $\begin{array}{l}\text { Soil } \\
\text { horizon }\end{array}$ & $\begin{array}{l}\text { Degree of peat } \\
\text { decomposition }\end{array}$ & $\begin{array}{l}\text { Water } \\
\text { ratio }\end{array}$ & $\begin{array}{l}\text { Bulk } \\
\text { density }\end{array}$ & $\begin{array}{l}\text { Total } \\
\text { porosity }\end{array}$ & $\begin{array}{l}\text { Water-filled pore } \\
\text { space }\end{array}$ & $\begin{array}{l}\text { Content of } \\
\mathrm{CaCO}_{3}\end{array}$ & $\begin{array}{l}\text { Mineral } \\
\text { fraction }\end{array}$ & $\begin{array}{l}\mathrm{pH} \\
\mathrm{H}_{2} \mathrm{O}\end{array}$ \\
\hline & $10-20$ & $\mathrm{Ha} 2$ & R3 & 58.8 & 0.43 & 75.4 & 77.9 & 6.1 & 33.0 & 7.5 \\
\hline & $20-30$ & $\mathrm{Lc}$ & & 56.2 & 0.55 & 74.9 & 75.0 & 51.3 & 19.6 & 7.8 \\
\hline & $30-40$ & & & 63.9 & 0.56 & 79.3 & 80.6 & 77.4 & 7.3 & 7.9 \\
\hline & $40-50$ & $\mathrm{Lm}$ & & 61.8 & 0.68 & 74.4 & 83.1 & 85.9 & 6.5 & 8.1 \\
\hline & $50-60$ & & & 65.7 & 0.65 & 75.3 & 87.3 & 88.6 & 4.9 & 8.1 \\
\hline & $60-70$ & & & 68.8 & 0.62 & 77.0 & 89.4 & 88.6 & 5.7 & 8.0 \\
\hline & $70-80$ & & & 66.7 & 0.65 & 75.3 & 88.6 & 89.1 & 4.8 & 8.1 \\
\hline \multirow[t]{9}{*}{7} & \multicolumn{10}{|c|}{ Hypereutric Regosol (Drainic, Humic) } \\
\hline & $0-10$ & Ha1 & & 44.7 & 0.37 & 80.1 & 55.8 & 3.6 & 29.1 & 7.2 \\
\hline & $10-20$ & $\mathrm{Ha} 2$ & R3 & 55.0 & 0.50 & 77.4 & 71.1 & 10.1 & 32.9 & 7.6 \\
\hline & $20-30$ & $\mathrm{Lc}$ & & 46.5 & 0.64 & 72.5 & 64.1 & 67.8 & 10.7 & 7.8 \\
\hline & $30-40$ & $\mathrm{Lm}$ & & 53.4 & 0.81 & 70.2 & 76.0 & 89.8 & 3.4 & 8.0 \\
\hline & $40-50$ & & & 61.4 & 0.70 & 75.0 & 81.9 & 87.0 & 6.5 & 8.0 \\
\hline & $50-60$ & & & 68.2 & 0.59 & 78.9 & 86.4 & 88.2 & 4.2 & 7.9 \\
\hline & $60-70$ & & & 69.3 & 0.62 & 78.2 & 88.7 & 81.6 & 10.9 & 7.9 \\
\hline & $70-80$ & & & 69.6 & 0.60 & 78.0 & 89.2 & 85.2 & 7.8 & 8.0 \\
\hline \multirow[t]{9}{*}{8} & \multicolumn{10}{|c|}{ Hypereutric Regosol (Drainic, Humic) } \\
\hline & $0-10$ & $\mathrm{Ha}$ & & 43.7 & 0.47 & 73.8 & 59.2 & 8.3 & 31.2 & 7.6 \\
\hline & $10-20$ & & & 51.8 & 0.51 & 73.4 & 70.6 & 25.1 & 26.1 & 7.4 \\
\hline & $20-30$ & $\mathrm{Lc}$ & & 48.5 & 0.80 & 66.9 & 72.5 & 73.3 & 10.7 & 7.8 \\
\hline & $30-40$ & $\mathrm{Lm}$ & & 55.2 & 0.68 & 73.9 & 74.7 & 89.0 & 2.7 & 8.1 \\
\hline & $40-50$ & & & 56.3 & 0.59 & 77.0 & 73.2 & 87.2 & 4.2 & 8.1 \\
\hline & $50-60$ & & & 60.7 & 0.61 & 76.0 & 79.9 & 84.4 & 5.2 & 7.9 \\
\hline & $60-70$ & & & 68.5 & 0.56 & 78.3 & 87.4 & 86.9 & 3.5 & 7.9 \\
\hline & $70-80$ & & & 71.0 & 0.56 & 79.9 & 88.9 & 86.8 & 6.3 & 8.0 \\
\hline
\end{tabular}

$\mathrm{pH}$ differences between peat and lake sediments occur in profiles 4-8.

Changes in the TOC and TN content were indicated in topsoil with different degrees of organic material mineralization. In profiles $1-3$, TOC contents ranged from 235.91 to $539.49 \mathrm{~g} \mathrm{~kg}^{-1}$ and TN from 17.01 to $38.44 \mathrm{~g} \mathrm{~kg}^{-1}$, with a relatively increasing trend from the top to the bottom part of the profiles (Fig. 4). In profiles 4-8, this dependency was reversed. Gyttja of the least transformed profiles (1 and 2) showed a very high content of TOC $\left(426.60 \mathrm{~g} \mathrm{~kg}^{-1}\right.$ on average) and $\mathrm{TN}\left(30.11 \mathrm{~g} \mathrm{~kg}^{-1}\right.$ on average), whereas moderately and strongly dehydrated profiles 4-8, on average, had up to $72.70 \mathrm{~g} \mathrm{~kg}^{-1}$ (TOC) and $4.66 \mathrm{~g} \mathrm{~kg}^{-1}$ (TN).

Increased $\mathrm{Fe}$ content was observed throughout the profiles of the most dehydrated soils (5-8), especially in the layer 10 $20 \mathrm{~cm}$ below the surface (Fig. 5), while increased Mg content occurred mainly below $20 \mathrm{~cm}$. At a depth below $20 \mathrm{~cm}$, there was a rapid decrease in Fe content. Lacustrine sediments localized in the bottom of profiles 4-8 were much poorer in specified elements than in profiles 1 and 2. In profiles $1-3$, $\mathrm{Fe}, \mathrm{Ca}$, and $\mathrm{Mg}$ contents were higher in topsoil than in the subsoil, in contrast to the more transformed soils (profiles 4 8 ) in which that trend was reversed. Al content was relatively similar in all profiles, with the highest values in surface horizons (4.40-7.49 $\mathrm{g} \mathrm{kg}^{-1}$ ); however, in profiles 1 and 2, values below $20 \mathrm{~cm}$ decreased by $3 \mathrm{~g} \mathrm{~kg}^{-1}$ on average, while in other profiles, these differences reached $6 \mathrm{~g} \cdot \mathrm{kg}^{-1}$. Similar regularity could be noted for $\mathrm{K}$ content, which achieved the highest values to a depth of about $20 \mathrm{~cm}\left(1.14-2.79 \mathrm{~g} \mathrm{~kg}^{-1}\right)$. Below this depth, $\mathrm{K}$ contents decreased to $0.05-1.01 \mathrm{~g} \mathrm{~kg}^{-1}$. In profiles 1 and 2, the difference between the maximum and minimum value was $1.15 \mathrm{~g} \mathrm{~kg}^{-1}$ on average, while in dehydrated profiles (4-8), this increased to $2.48 \mathrm{~g} \mathrm{~kg}^{-1}$. In these profiles, a decrease in the $\mathrm{K}$ content with depth was clearly marked. The highest $\mathrm{P}$ contents were observed to the depth of $20 \mathrm{~cm}$ in drained profiles $\left(2.18-2.80 \mathrm{~g} \mathrm{~kg}^{-1}\right)$. In all profiles, below 20 $\mathrm{cm}$, there is a sudden decrease in P content (to $0.06-0.84 \mathrm{~g}$ $\mathrm{kg}^{-1}$ ). In profiles $1-3$, there were also smaller differences in $\mathrm{P}$ contents between surface and deeper horizons. TOC/TN ratio ranged between 12.1 and 20.0. The greatest differences were visible from the depth of $20 \mathrm{~cm}$ to the bottom part. In profiles 2 and 3, the range was wider and reached maximum values 
Fig. 4 Selected chemical properties of the studied soils
TOC $\left[\mathrm{g} \mathrm{kg}^{-1}\right]$

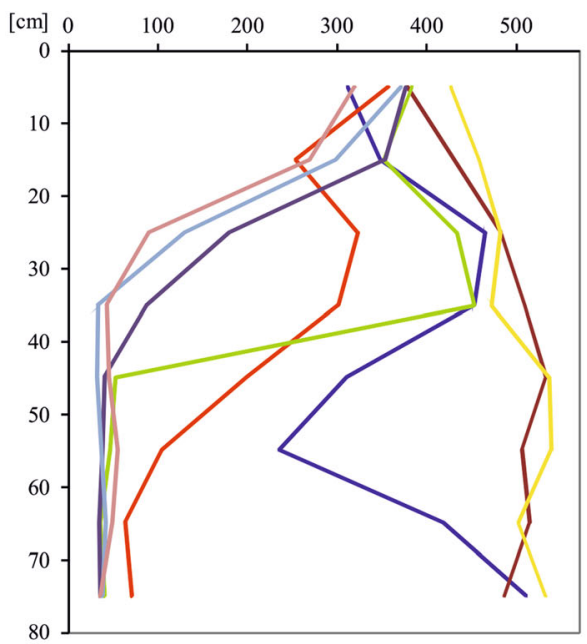

P [ $\left.\mathrm{g} \mathrm{kg}^{-1}\right]$

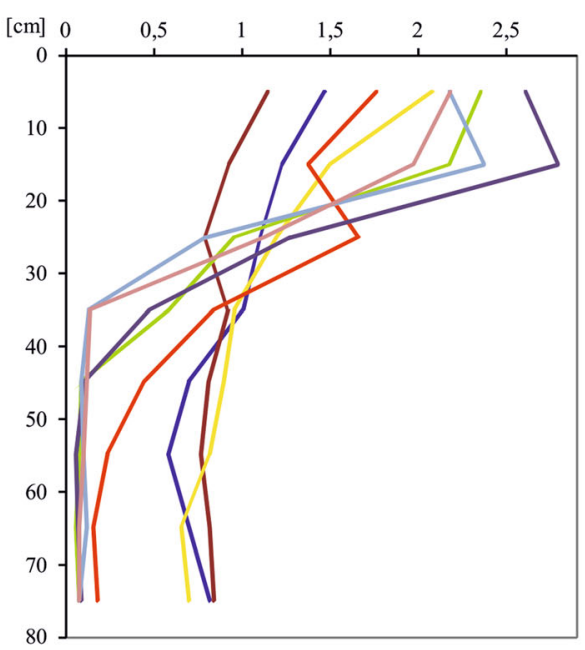

TN/P

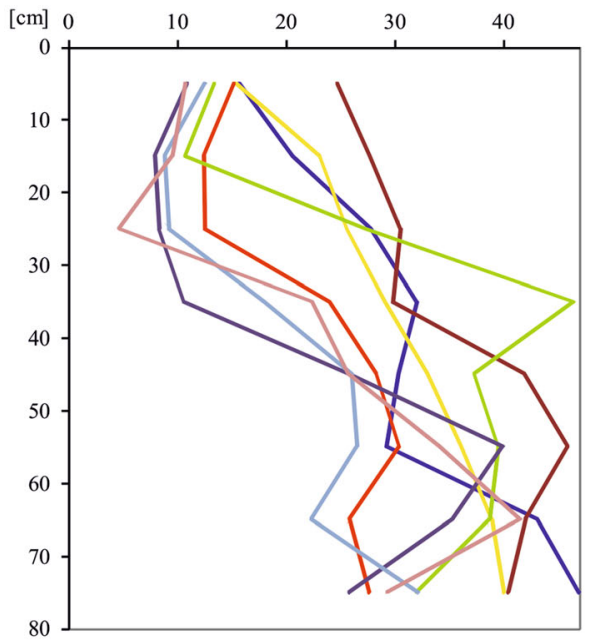

$\mathrm{TN}\left[\mathrm{g} \mathrm{kg}^{-1}\right]$

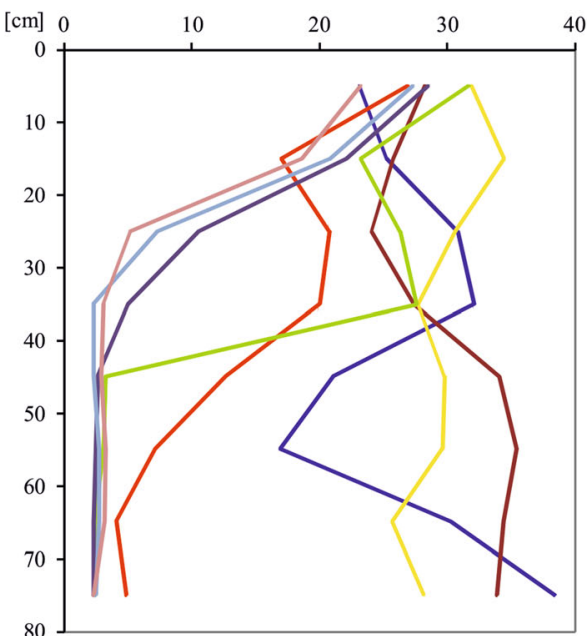

TOC/TN

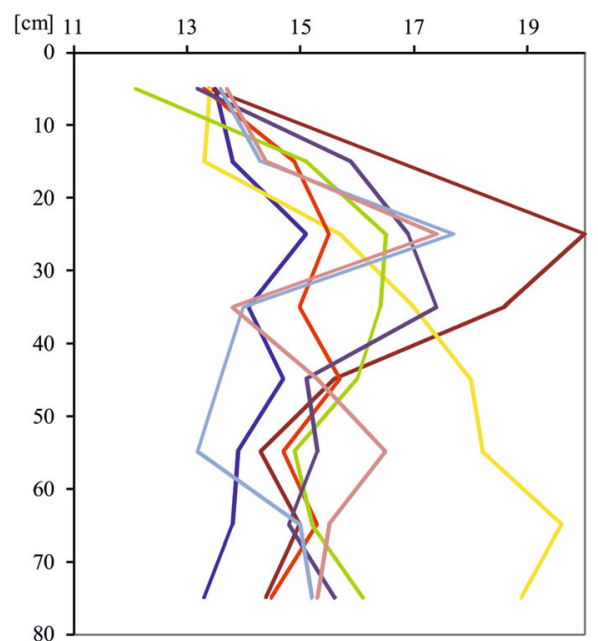

$\mathrm{TOC} / \mathrm{P}$

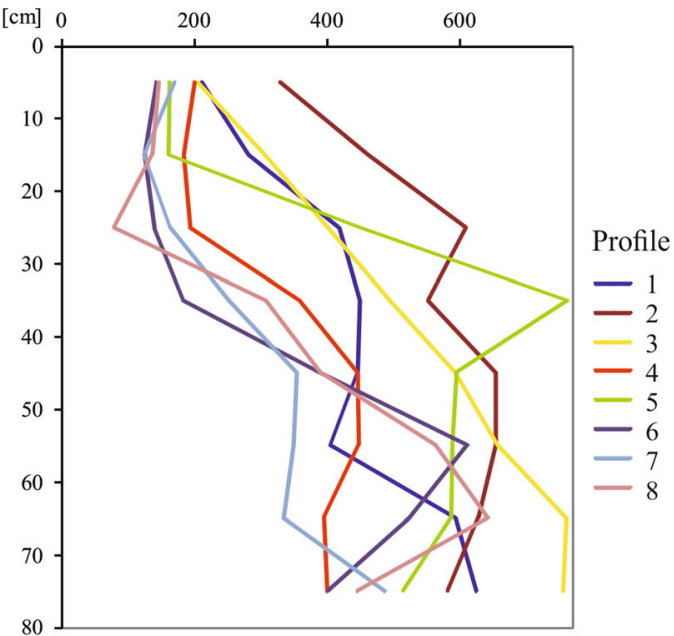


Fig. 5 Content of $\mathrm{K}, \mathrm{Ca}, \mathrm{Fe}, \mathrm{Mg}$, and $\mathrm{Al}$ in the studied soil profiles
$\mathrm{K}\left[\mathrm{g} \mathrm{kg}^{-1}\right]$

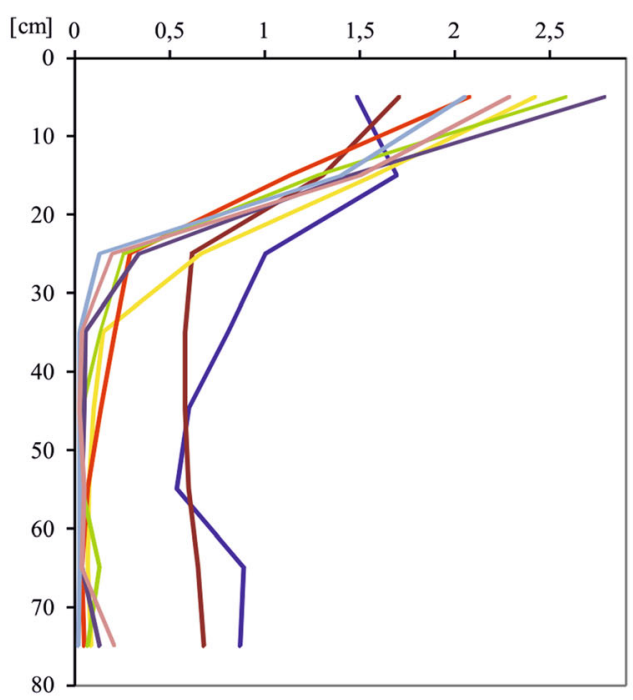

$\mathrm{Fe}\left[\mathrm{g} \mathrm{kg}^{-1}\right]$
$\mathrm{Ca}\left[\mathrm{g} \mathrm{kg}^{-1}\right]$

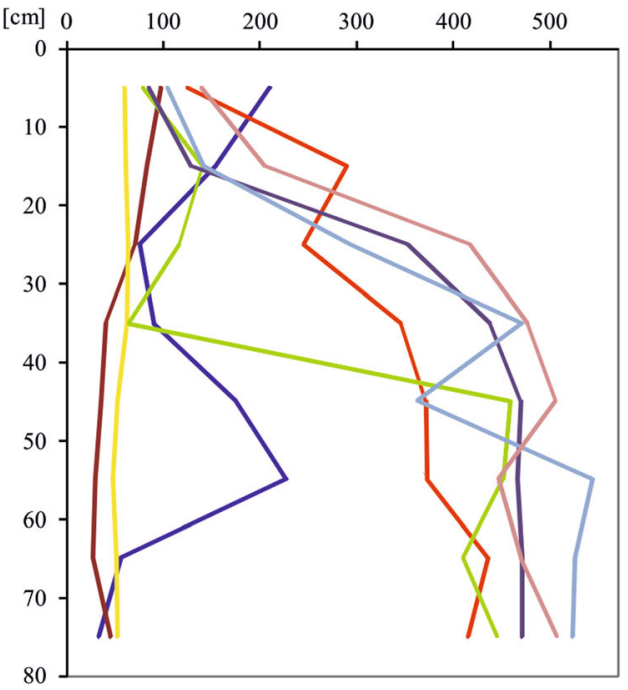

$\mathrm{Mg}\left[\mathrm{g} \mathrm{kg}^{-1}\right]$
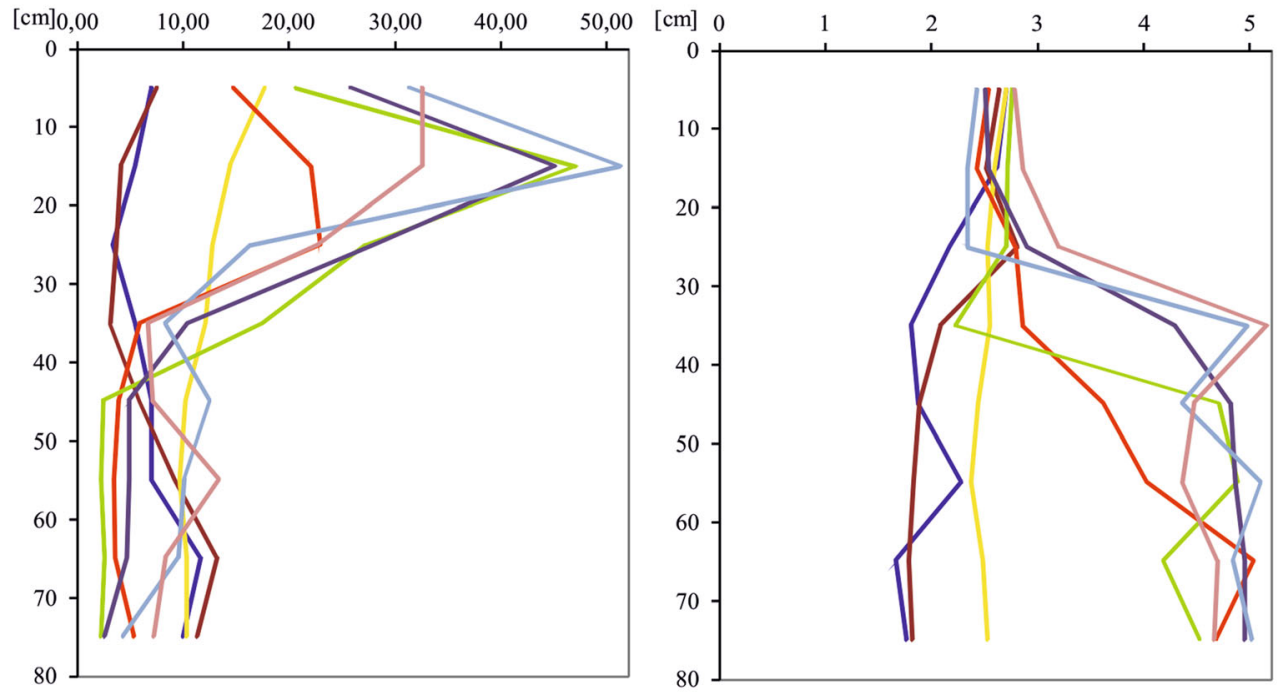

$\mathrm{Al}\left[\mathrm{g} \mathrm{kg}^{-1}\right]$

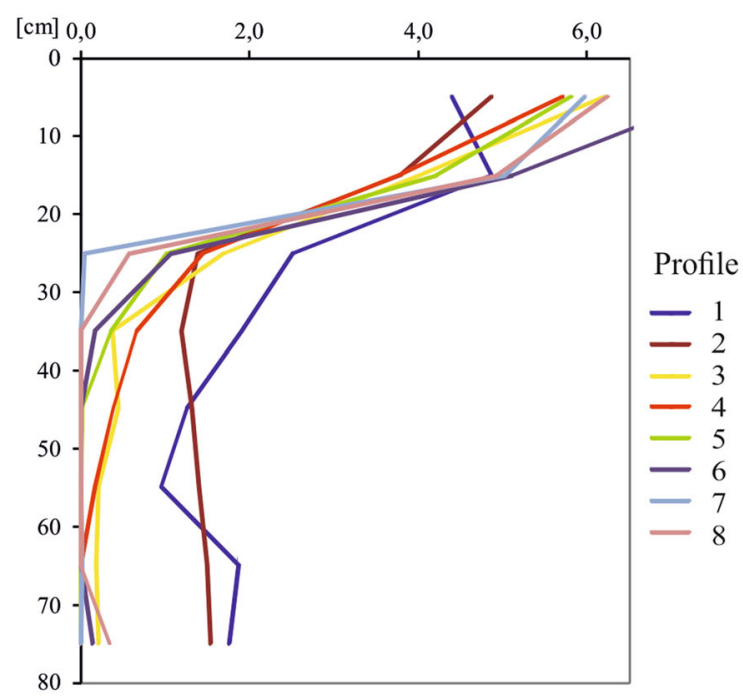


(over 18) in the middle and bottom parts. A narrower range of TOC/TN values (13-15) was characteristic for profile 1 located in the immediate vicinity of the lake's current surface. The TOC/P and TN/P profile distribution patterns were fairly similar in each profile, while an increase in the value of these indicators was observed below the depth of $30 \mathrm{~cm}$. Surface horizons of drained soils were characterized by values on average $60(\mathrm{TOC} / \mathrm{P})$ and $5(\mathrm{TN} / \mathrm{P})$ units smaller than in other profiles (Fig. 4). On the basis of all the studied profiles, profile 2 was untypical: the average value of the TOC/P index was 559 (with values from 279 to 522 in other profiles), and TN/ P-35 (with values of 19-30 for other profiles).

\subsection{Mineral composition of the soils}

The topsoil of the studied soils were rich in organic matter which resulted in high background and noises in the XRD patterns of these samples (Fig. 6). The predominance of organic matter was also confirmed by results of TOC analysis (Fig. 4). Moreover, organic materials contained admixtures of quartz and calcite (Fig. 6).

Calcite was the major mineral in the lacustrine sediments occurring in subsoil of the studied soils (Fig. 6). Moreover, minor amounts of aragonite were determined in several samples in the upper part of lacustrine chalk layers in contact with organic material layers (e.g., profiles 6 and 8). Aragonite occurred in those horizons where shells of molluscs were found. There was a weak broad peak $0.604 \mathrm{nmin}$ the XRD patterns of samples from the subsoil. This peak most likely belonged to bassanite. Trace amounts of goethite and wavellite were found in the subsoil of profile 8 (Fig. 6).

\section{Discussion}

\subsection{Phases of soil cover development as an effect of lake water level changes}

Radiocarbon ages of lake sediments collected to the depth of $785 \mathrm{~cm}$ in Lake Rakutowskie presented by Harasimiuk et al. (2010) encompassed dates between $5590 \pm 60 \mathrm{cal}$. BP (at the depth of about $200 \mathrm{~cm}$ ) and $11,730 \pm 100 \mathrm{cal}$. BP in the bottom part of the core, which indicates the existence of a reservoir at least from the Allerød. Dates obtained from the samples collected from the bottom part of a $735 \mathrm{~cm}$ deep core from Lake Żłoby were older (to 14,530 BP; mean 15,792 cal. $\mathrm{BCE}$ ) and were determined in the fine sand layer which indicates an accumulation process in the Late Glacial period. These data correspond to those for other lakes from central Poland (Manikowska 1992; Więckowski 1993; Tobolski 1998). The current lake area may vary between 200 and 400 ha depending on the period of the year (Harasimiuk et al. 2010). The oldest Histosols, located at a distance of
$1200 \mathrm{~m}$ from the lake within the study area, were dated to 5856 cal. BCE which indicates that the water level of Lake Rakutowskie was already in decline in the Atlantic period and that it gradually lowered in the subsequent decades. Due to the occurrence of lake sediments at further distances from the studied transect, it is highly probable that the water level decrease took place much earlier. In the past, Lake Rakutowskie and neighboring Lake Żłoby were probably part of a broad basin with deeper water parts within Lake Żłoby.

The results obtained based on the sequence of the investigated profiles (Figs. 2 and 3) clearly show the transformations of organic soils (Histosols) along with disappearance of a lake. The phases of soil-forming processes in the immediate vicinity of Lake Rakutowskie were closely related to water level fluctuations. Shallow lake sediments such as those of Lake Rakutowskie may be considered as soils provided they were permanently submerged by water not deeper than $200 \mathrm{~cm}$ (IUSS Working Group WRB 2015). In the studied area, this condition could probably be met, especially on the outskirts of the lake. For this reason, we assumed that all studied soils before dehydration could primarily be hypothetically classified as Subaquatic Histosols (Limnic) and Subaquatic Histosols (IUSS Working Group WRB 2015). This stage (underwater soil phase-P1) can be treated as the first phase of soil cover development in this area. According to, e.g., Demas et al. (1996), Demas and Rabenhorst (1999), and Erich et al. (2010), aquatic substrates (sediments) in shallow lakes can be transformed into soils as a result of pedogenic processes. The second phase (P2) after the water table lowering and terrestrialization was characterized by full soil saturation with water without traces of peat degradation. This stage was observed in profiles 1 and 2 . The next stage of soil development (P3) was represented by profile 3, where as a result of significant water table decrease, the first signs of peat degradation were observed in topsoil. Phase four (P4) was characterized by significant dehydration and clearly marked degradation of peat, which was observed in profiles 4 and 5. Permanent drainage of the area caused a phase of deep peat degradation as a result of the advanced mursh formation process (P5) which is represented by profiles $6-8$. The presence of limnic material in Regosols profiles may contribute to the inclusion of Limnic as additional supplementary qualifier in relation also to Regosols which is missing in the current version of the WRB classification.

\subsection{Soil physical and chemical properties modified as a result of changes in hydrological conditions}

Gradual lake drainage led to a decrease in its range and consequently to peatland formation and then to intensification of peat decomposition. Peatland functioning is closely related mainly to hydrological conditions (Strack 2008), which in cases of its radical change can have a strong impact on organic 
Fig. 6 XRD patterns for the selected soil samples. (A) Profile $1(50-60 \mathrm{~cm})$. (B) Profile $2(0-10$ cm. (C) Profile 4 (40-50 cm), (D) Profile 4 (70-80 cm). (E) Profile 5 $(10-20 \mathrm{~cm})$. (F) Profile $6(0-10$ $\mathrm{cm})$. (G) Profile $6(20-30 \mathrm{~cm})$. (H) Profile 6 (70-80 cm). (I) Profile 7 (10-20 cm). (J) Profile 8 $(0-10 \mathrm{~cm}),(\mathrm{K})$ Profile 8 (20-30 $\mathrm{cm})$, (L) Profile $8(50-60 \mathrm{~cm})$. (M) Profile $8(70-80 \mathrm{~cm})$. The $d$ values (in brackets in the upper part of the figure) are in $\mathrm{nm}$. Symbols of mineral phases: A aragonite, $\mathrm{B}$ bassanite, $\mathrm{C}$ calcite, G goethite, Q quartz, W wavellite

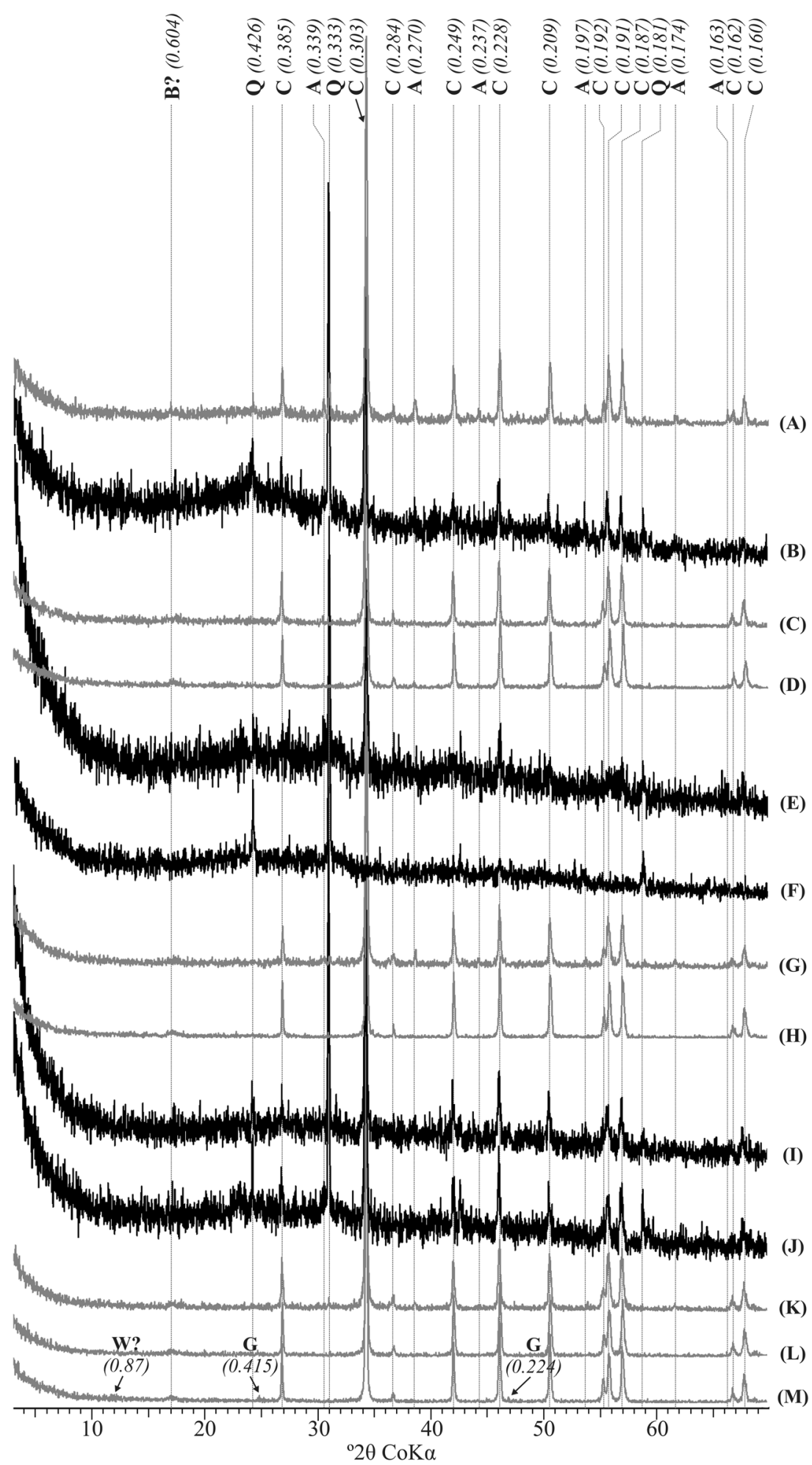

soils. The first noticeable effects of drainage are changes in soil morphology, structure, and physical properties. Mursh is the final product of intensive and long-term dehydration. This process, especially under conditions of constant peat soil drainage, leads to structural changes in soil profiles, gradual delamination of the peat layer and, as a result, its increasing permeability. Differences in soil morphology modifications depend on the distance from the current lake surface. Groundwater level lowering in soils enhances the progressive vegetation succession. Peat dehydration causes its progressive degradation and mursh formation by the intensive mineralization of organic material, which affects the content of elements 
(Figs. 4 and 5). Such a pattern has also been observed by other researchers (Berglund 1996; Chmieleski et al. 2004; Gonet et al. 2010; Mendyk et al. 2014; Markiewicz et al. 2015; Glina et al. 2016a, b). Degraded peatlands with desiccated soils have a damaged ecosystem which cannot function properly. In profiles located at the shortest distance from the present lake surface, water level ranged from 20 (1) to $40 \mathrm{~cm}$ (3) below soil surface, while in other profiles this was deeper than $80 \mathrm{~cm}$. Deterioration of soil physical properties as a result of desiccation is reflected in a increase of the bulk density and decrease of soil porosity and also a higher percentage of mineral fraction in primarily organic sediments, similar to other studies (e.g., Hobbs 1986; Myślińska 2003). In profiles 4-8, murshic soils have been formed with degraded top parts of peat. The best preserved morphology of deep Histosols was observed in profile 3 , where peat material was preserved with lacustrine sediments below $100 \mathrm{~cm}$. The peat dehydration process causes a significant deterioration of the physical properties of these soils (e.g., Renger et al. 2002; Kechavarzi et al. 2010; Kiryluk 2017). In the study area, this relationship increases with the distance from the contemporary lake range. The progressive decrease in groundwater level caused a significant acceleration of peat decomposition, which is particularly evident in profiles 4-8. In these profiles, a significant degree of decomposition covers the entire layer of peat material. In other profiles (1-3), in which groundwater occurred at a depth of $20-40 \mathrm{~cm}$, the intensive peat decomposition process was observed only within topsoil.

Peatlands constitute a major terrestrial carbon stock. The problem of organic soil dehydration is closely related to the loss of organic carbon, soil usability, and development resulting in an imbalance in peatland ecosystems (Gonet and Markiewicz 2007). Changes to organic matter in soils occur with varied intensity, expressed as a TOC/TN ratio. The studied profiles were characterized by relatively similar TOC/TN ratios; however, higher values (17.0-20.0) in the bottom part of profile 3 and the middle part of profile 2 could be an indicator of organic matter mineralization slowdown. All surface horizons were subjected to enhanced mineralization processes which is evidenced by lower TOC/TN values (12.1-13.5). Under the influence of the mursh forming process, the content of TN increases by $30 \%$, while the content of TOC decreases (Piaścik and Gotkiewicz 2004). Soil pH in the studied transect was closely related to characteristics of peat and lacustrine sediments. In view of these reactions, the studied profiles can be divided into two groups: (i) soils with relatively homogenous $\mathrm{pH}$ across the whole profile and with a marked influence of organic soils on lacustrine sediment reactions (profiles 1-3), and (ii) dehydrated soils with clear reaction changes at the border of organic and lacustrine sediments and marked lacustrine sediment impacts on $\mathrm{pH}$ of overdried soils (profiles 4-8). The presence of $\mathrm{Ca}$ in organic horizons and thus high $\mathrm{pH}$ values, could be correlated with the capillary ascension of water and pedogenic calcite crystallization in organic materials. The large quantities of calcium ions present in solution in the peat layer could also be a result of organic matter binding (Lucas 1982; Okruszko 1976b).

The two or three times higher contents of iron in murshic horizons than in peat may be caused by organic matter mineralization enhancement or oxidation processes intensification (Mocek et al. 2007). Differences, especially in Fe content, between each profile resulted from the rate of the drying process, which first occurs in surface horizons and currently covers the greater part of the Rakutowskie catchment. In overdried Histosols, iron has an increased ability to form complex compounds with an organic substance, which is confirmed by other researchers (Henrot and Wieder 1990; Norrstrom 1995). Iron in the mursh material comes from the peat mineralization process and from groundwater, and it precipitates in the form of oxyhydroxides. A high Fe content in murshic horizons is an indication of increased oxidation and reduction processes and also of intensive mineralization and biological accumulation (Puustrjarvi 1952; Sapek and Sapek 1987). The zone of oxidation in overdried soils can be located at different depths depending on the type of water regime.

The mineral composition of the studied soils is different in the subsoil (a layer of lacustrine deposits) and the topsoil (a layer of organic material). The mineral composition of the subsoil of the studied soils is typical for similar formations in temperate climatic zones. Calcite is the major mineral phase occurring in the lacustrine chalk and certain gyttja types (Wyrwicki 2001; Raukas and Tavast 2002; Maćkowska 2008) present in the subsoil of the studied profiles. Bassanite has previously been found in lacustrine chalk (Maćkowska 2011). This mineral is likely to be an effect of the reaction of weathered pyrite with Ca carbonates occurring in lacustrine chalk (Maćkowska 2011). The lacustrine chalk layer contained numerous shells and therefore contained aragonite. That mineral is one of the major components of mollusc shells (Medaković et al. 2003). Particularly high contents of aragonite occurred typically in the upper part of lacustrine chalk layer in the studied soil profiles (e.g., profiles 6 and 8) (Fig. 6). As mentioned above, the calcite genesis in organic horizons is probably related to the capillary ascension of water and calcite crystallization in organic materials. Quartz present in organic layers of the studied soils is most likely an allochthonous phase.

\subsection{Impact of human and land use changes on soil transformations}

Changes of the lake range caused mainly by anthropogenic factors led to rapid overgrowth of the former lake surface by reed beds, willow clumps, etc., and as a result, soil formation and their progressive overdrying. This process was also observed by other research (Ralska-Jasiewiczowa and van Geel 
1992; Smith et al. 2005; Kinder et al. 2009; Dietze et al. 2016; Skowron and Jaworski 2017; Słowiński et al. 2019). Based on the radiocarbon dating results, we can observe the gradual process of the Lake Rakutowskie disappearance (Table 1). Reduction of the lake surface within 75 years from 329.3 to 101.8 ha has accelerated significantly in the last century, and this has an undeniable connection with land use changes in the lake catchment, drainage, and fertilization. The results indicate a significant acceleration of the disappearance of the lake after the implementation of drainage treatments. This process before the melioration was introduced was slow and gradual. Soil morphology furthest away from the contemporary lake surface indicates that peat was degraded completely. The drainage of the area by humans has undoubtedly accelerated this process.

In the early phase of the lakes functioning, they were mainly dependent on precipitation, river water inflow, evaporation, and the variable relationship between natural erosion and accumulation processes leading to gradual lake shallowing (Tobolski 2000; Kramkowski et al. 2014; Ott et al. 2017). Analysis of archival cartographic documentation of the immediate vicinity of Lake Rakutowskie indicates the increased impact of human activity as early as the beginning of the twentieth century (Kramkowski et al. 2014; Bartczak et al. 2019). Initially, this work consisted of the regulation of watercourses, and then by 1930 , a network of drainage ditches was established. Further regulatory work on the watercourses led to a significant reduction of the lake area from 329.3 ha (in 1930) to 226.8 ha by 1945 . Since the 1960s, the lake area was still rapidly changing. The next phase was the overgrowth of watercourses and more intensive use of adjacent meadows for agricultural purposes. Together with the lowering of the lake's water level, new bottom fragments emerged, which have gradually overgrown. This process led to a lake area decrease to 101.8 ha by 2009 (Kramkowski et al. 2014). On the basis of observations of the lake's range over the last 100 years, a significant acceleration of the lake's rate of decline is clearly visible in relation to the period before the intensification of anthropic pressure. Analogous results have also been obtained during research on other lakes (e.g., Mendyk et al. 2014, 2016; Markiewicz et al. 2015). The obtained $\mathrm{C}^{14}$ dates indicate a significant acceleration of the lake's disappearance process over the last 300 years. However, in relation to the results presented in Fig. 2, the fastest decay rate is in the last 70 years. Similar processes are observed in other European countries (e.g., Coops and Hosper 2002; Battarbee and Bennion 2011; Ventelä et al. 2015).

Our studies have shown that soil sequence analysis in the shoreline of disappearing lakes may be an indicator of environmental changes and the basis for reconstruction of former lake ranges. Soil surveys are a valuable complement to other forms of research (hydrological, ecological, etc.).

\section{Conclusions}

As a result of more than 12, 000 years of evolution, Lake Rakutowskie has been subjected to lake water level changes. In the past decades, the rate of Lake Rakutowskie disappearance has accelerated due to human activity causing irreversible ecosystem changes. The whole area of the former Lake Rakutowskie bottom is covered with soils originating from lacustrine sediments and gyttja covered with organic materials (peat and mursh) characterized by varied thicknesses and degrees of decomposition. However, a significant acceleration of this process is undoubtedly related to human activity in the immediate catchment (land use changes, melioration, and eutrophication associated with agriculture). Progressive soil dehydration has taken place since 1945, when the lake area was reduced by $30 \%$, which led to vegetation succession on exposed parts of the former lake bottom. According to soil morphology, five phases of soil development were specified, from the stage of subaqueous soils (Subaquatic Histosols (Limnic) and Subaquatic Histosols) still observed in the shallow parts of the lake, to the 5th phase represented by Hypereutric Regosol (Drainic, Humic ) profiles, which began at latest during the Atlantic period (5856 cal BCE $\left(6970 \pm 70{ }^{14} \mathrm{C} \mathrm{BP}\right)$ ). The study stand is characterized by low variability of soil morphology, however differing in peat thickness and its decomposition degree (composed of peat, mursh, and lacustrine sediments) which indicates the relative homogeneity of the conditions of their development affected by the former lake range. Different degrees of soil dehydration influenced soil morphology (changes of peat decomposition degree), and soil physical (decrease in total porosity and increase in bulk density, higher percentage of mineral fraction content, etc.) and chemical properties. In the analysis of soil property changes, the distance from an existing lake plays an important role. The most intensive transformations were characteristic for TOC, $\mathrm{TN}, \mathrm{Fe}, \mathrm{Al}, \mathrm{Mg}, \mathrm{Ca}$, and $\mathrm{P}$ contents in surface horizons. The calcite content results from the past/present impact of lacustrine sediments. Despite the organic matter, quartz and calcite predominate in the mineral composition of topsoil. In the subsoil, aragonite, basanite, and also trace amounts of wavellite and goethite occurred. It can be predicted that the area of dehydrated ecosystems in the vicinity of Lake Rakutowskie will gradually increase due to the strong impact of drainage and changes in lake trophic status as a result of the supply of artificial fertilizers from the surrounding arable fields causing a further decline in the lake's water level. The results can be extrapolated to similar postglacial areas in temperate climatic zones. Additionally, these studies showed that term Limnic 
should be added as supplementary qualifier in relation to Regosols in the WRB classification.

Acknowledgements Prof. A. Łachacz (University of Warmia and Mazury in Olsztyn, Poland) is acknowledged for his kind help during the preparation of the text.

This study is a contribution to the project NCN 015/17/B/ST10/03430, NCN 2015/19/N/ST10/02655 and POIŚ.05.01.00-00-362/12.

Open Access This article is licensed under a Creative Commons Attribution 4.0 International License, which permits use, sharing, adaptation, distribution and reproduction in any medium or format, as long as you give appropriate credit to the original author(s) and the source, provide a link to the Creative Commons licence, and indicate if changes were made. The images or other third party material in this article are included in the article's Creative Commons licence, unless indicated otherwise in a credit line to the material. If material is not included in the article's Creative Commons licence and your intended use is not permitted by statutory regulation or exceeds the permitted use, you will need to obtain permission directly from the copyright holder. To view a copy of this licence, visit http://creativecommons.org/licenses/by/4.0/.

\section{References}

Baraniecka MD (1993) Objaśnienie do Szczegółowej Mapy Geologicznej Polski 1:50 000 Arkusz Lubień Kujawski. PIG, Warszawa (in Polish)

Bartczak A (2007) Wieloletnia zmienność odpływu rzecznego z dorzecza Zgłowiączki. IGiPZ PAN.164 (in Polish)

Bartczak A, Słowińska S, Tyszkowski S, Kramkowski M, Kaczmarek H, Kordowski J, Słowiński M (2019) Ecohydrological changes and resilience of a shallow lake ecosystem under intense human pressure and recent climate change. Water 11(1):32

Battarbee RW, Bennion H (2011) Palaeolimnology and its developing role in assessing the history and extent of human impact on lake ecosystems. J Paleolimnol 45:399-404

Becher M, Kalembasa D, Pakula K, Malinowska E (2013) Carbon and nitrogen fractions in drained organic soils. Environ 4(58):1-5

Berglund K (1996) Properties of cultivated gyttja soils. Int Peat J 6:5-23

Birks HJB, Birks HH (1980) Quaternary palaeoecology. Edward Arnold, London

Bogacz A, Andrzejczak M, Tomaszewska K, Podlaska M (2019) Anthropogenic impact on concentration of selected trace elements pools in transformed organic soils in Trzcińskie Mokradła Peatland, SW Poland. Soil Sci Annu 70(4):283-291

Bronk Ramsey C, Lee S (2013) Recent and planned developments of the program OxCal. Radiocarbon 55

Charman D (2002) Peatlands and environmental change. Wiley

Chmieleski J, Schleier C, Zeitz J (2004) Pedogenesis, physical and chemical properties of drained former lacustrine soils in central Europe, 12th International Peat Congress Tampere. Finland. 6-11(06):300305

Choiński A, Ławniczak AE, Ptak M, Sobkowiak L (2011) Causes of lake area changes in Poland. J Resour Ecol 2:175-180

Choiński A, Ptak M, Ławniczak AE (2016) Changes in water resources of Polish lakes as influenced by natural and anthropogenic factors. Pol J Environ Stud 25:1883-1890

Cohen AS (2003) Paleolimnology, The history and evolution of lake systems. Oxford University Press, New York

Coops H, Hosper SH (2002) Water-level management as a tool for the restoration of shallow lakes in The Netherlands. Lake Reservoir Manag 18:293-298
Demas GP, Rabenhorst MC (1999) Subaqueous soils: pedogenesis in a submersed environment. Soil Sci Soc Am J 63:1250-1257

Demas GP, Rabenhorst MC, Stevensen JC (1996) A pedologial approach to the study of shallow-water habitats. Estuaries 19:229-237

Dietze E, Słowiński M, Zawiska I, Veh G, Brauer A (2016) Multiple drivers of Holocene lake level changes at a lowland lake in northeastern Germany. Boreas 45:828-845

Długosz J, Kalisz B, Łachacz A (2018) Mineral matter composition of drained floodplain soils in north-eastern Poland. Soil Sci Annu 69(3):184-193

Dziadowiec H, Gonet SS (1999) Przewodnik metodyczny do badań materii organicznej gleb. Prace Komisji Naukowych PTG. (in Polish)

Erich E, Drohan PJ, Ellis LR, Collins ME, Payne M, Surabian D (2010) Subaqueous soils: their genesis and importance in ecosystem management. Soil Use Manag 26:245-252

FAO (2006) Guidelines for soil description. 4th ed. ftp://ftp.fao.org/agl/ agll/docs/guidel soil descr.pdf. Rome

Glazik R (1978) Wpływ zbiornika wodnego na Wiśle we Włocławku na zmiany stosunków wodnych w dolinie. Dokumentacja Geograficzna 2-3:119 (in Polish)

Glina B, Bogacz A, Woźniczka P (2016a) Nitrogen mineralization in forestry-drained peatland soils in the Stołowe Mountains National Park (Central Sudetes Mts). Soil Sci Annu 67:64-72

Glina B, Gajewski P, Kaczmarek Z, Owczarzak W, Rybczyński P (2016b) Current state of peatland soils as an effect of long-term drainage - preliminary results of peatland ecosystems investigation in the Grójecka Valley (central Poland). Soil Sci Annu 67:3-9

Gonet SS, Markiewicz M (2007) Rola materii organicznej w środowisku (The role of soil organic matter in environment). PTSH, Wrocław (in Polish)

Gonet SS, Markiewicz M, Marszelewski W, Dziamski A (2010) Soil transformations in catchment of disappearing Sumówko Lake (Brodnickie Lake District, Poland). Limnol Rev 10:133-137

Guttman NB (1999) Accepting the standardized precipitation index: a calculation algorithm. J Am Water Resour Assoc 35(2):311-322

Harasimiuk A, Wicik B, Grabowski T (2010) The lake deposits in Płock Basin (case studies of Lakes Rakutowskie and Żłoby). Limnol Rev 10(1):23-28

Henrot J, Wieder RK (1990) Processes of iron and manganese retention in laboratory peat microcosms subjected to acid mine drainage. J Environ Qual 19:312-320

Hernandez-Almeida I, Grosjean M, Gomez-Navarro JJ, Larocque-Tobler I, Bonk A, Enters D, Ustrzycka A, Piotrowska N, Przybylak R, Wacnik A, Witak M, Tylmann W (2016) Resilience, rapid transitions and regime shifts: fingerprinting the responses of Lake Zabinskie (NE Poland) to climate variability and human disturbance since AD 1000. The Holocene 27:258-270

Hobbs NB (1986) Mire morphology and the properties and behaviour of some British and foreign peats. Q J En Geol 19:7-80

IUSS Working Group WRB (2015) World Reference Base for Soil Resources 2014, update 2015. International soil classification system for naming soils and creating legends for soil maps. World Soil Resources Reports No. 106. FAO, Rome http://www.fao.org/3/ i3794en/13794en.pdf

Jassey VE, Chiapusio G, Binet P, Buttler A, Laggoun-Défarge F, Delarue F, Bernard N, Mitchell EAD, Toussaint ML, Francez AJ, Gilbert D (2013) Above- and belowground linkages in Sphagnum peatland: climate warming affects plant-microbial interactions. Glob Chang Biol 19:811-823

Kalinowska K (1961) Zanikanie jezior polodowcowych w Polsce (Disappearance of post-glacial lakes in Poland). Przeegląd Geograficzny, XXXIII

Kechavarzi C, Dawson Q, Leeds-Harrison PB (2010) Physical properties of low-lying agriculture peat soils in England. Geoderma 154:196202 
Kinder M, Turczyński M, Tylmann W (2009) Sedimentation rates and erosion changes recorded in recent sediments of Lake Piaseczno, south-eastern Poland. Geologija 51:125-130

Kiryluk A (2017) Changes of the physical-waters properties of murshic endofibric histosols in the aspect of long-term investigation on the drainage object Supraśl Dolna. J Ecol Eng 18(5):90-95

Kramkowski M, Bartczak A, Kaczmarek H, Słowiński M, Tyszkowski S (2014) Naturalne i antropogeniczne uwarunkowania przestrzennych zmian obszarów wodno-błotnych na przykładzie Jeziora Rakutowskiego w świetle archiwalnych materiałów kartograficznych i fotogrametrycznych. Prob Ekol Kraj 37 (in Polish)

Kruczkowska B (2016) The use of kettle holes for reconstructing former soil cover in different types of land use. Geogr Pol 89(3):323-343

Kruczkowska B, Błaszkiewicz M, Jonczak J, Uzarowicz Ł, Moska P, Brauer A, Bonk A, Słowiński M (2020) The Late Glacial pedogenesis interrupted by aeolian activity in Central Poland - Records from the Lake Gościaż catchment. Catena, 185, 104286.Lamentowicz M, Tobolski K, Mitchell EAD (2007) Palaeoecological evidence for anthropogenic acidification of a kettle-hole peatland in northern Poland. The Holocene 17:1185-1196

Lamentowicz M, Słowińska S, Słowiński M, Jassey VEJ, Chojnicki BH, Reczuga MK, Zielińska M, Marcisz K, Lamentowicz Ł, Barabach J, Samson M, Kołaczek P, Buttler A (2016) Combining short-term manipulative experiments with long-term palaeoecological investigations at high resolution to assess the response of Sphagnum peatlands to drought, fire and warming. Mires Peat 18(20):1-17

Lorenc H (1994) Ocena zmienności temperatury powietrza i opadów atmosferycznych w okresie 1901-1993 na podstawie obserwacji z wybranych stacji meteorologicznych w Polsce (Assessment of air temperature and precipitation variability in the period 1901-1993 on the basis of observations from selected meteorological stations in Poland). Wiad IMGW 38:43-59 (in Polish)

Lucas R (1982) Organie soils histosols. In: Michigan State Univ. East Lansing, Research Report

Maćkowska R (2008) Preliminary results of the mineral composition of lacustrine chalk and gyttja in relation to modern investigation methods. Biuletyn Państwowego Instytutu Geologicznego 429:7578

Maćkowska R (2011) Diagenesis of lacustrine chalk and gyttja in Holocene deposits from northwestern Poland. Biuletyn Państwowego Instytutu Geologicznego 444:149-156

Manikowska B (1982) Gleby kopalne w wydmach Polski środkowej (Fossil soils in dunes of central Poland). Roczniki GleboznawczeSoil Sci Annu 33:119-133

Manikowska B (1991) Vistulian and Holocene aeolian activity, pedostratygraphy and relief evolution in Central Poland. Z Geomorphol 90:131-141

Manikowska B (1992) Gleby kopalne w osadach z okresu 20 000-8 000 lat BP w Polsce (Fossil soils in sediments between 20000 and 8000 years BP in Poland). Prz Geol 10:588-600 (in Polish)

Marcisz K, Lamentowicz Ł, Słowińska S, Słowiński M, Muszak W, Lamentowicz M (2014) Seasonal changes in Sphagnum peatland testate amoeba communities along a hydrological gradient. Eur J Protistol 50:445-455

Marcisz K, Tinner W, Colombaroli D, Kołaczek P, Słowiński M, Fiałkiewicz-Kozieł B, Łokas E, Lamentowicz M (2015) Longterm hydrological dynamics and fire history over the last 2000 years in CE Europe reconstructed from a high-resolution peat archive. Quat Sci Rev 112:138-152

Markiewicz M, Mendyk Ł, Gonet SS (2015) Soil organic matter status in agricultural soil sequence of former shoreline of disappearing Sumowskie lakes, North-Eastern Poland. Pol J Soil Sci 48:65-78

Markiewicz M, Gonet SS, Marszelewski W, Mendyk Ł, Sykuła M (2017) Differentiation of soils and land use changes in the vicinity of disappeared Gardeja lake (Northern Poland). Soil Sci An 68:115-124
Medaković D, Slapnik R, Popović S, Gržeta B (2003) Mineralogy of shells from two freshwater snails Belgrandiella fontinalis and B. kuesteri. Comp Biochem Physiol A Mol Integr Physiol 134:121127

Mendyk Ł, Markiewicz M, Świtoniak M (2014) Catchments of disappearing lakes in glacial meltwater landscapes (Brodnica lake District). Wyd. Nauk, UMK, Toruń

Mendyk Ł, Markiewicz M, Bednarek R, Świtoniak M, Gamrat WW, Krześlak I, Sykuła M, Gersztyn L, Kupniewska A (2016) Environmental changes of a shallow kettle lake catchment in a young glacial landscape (Sumowskie Lake catchment), NorthCentral Poland. Quat Int 418:116-131

Mocek A, Spychalski W, Gajewski P (2007) Content of trace elements in hydrogenic soils of the Grójec Valley. Ochrona Środowiska i Zasobów Naturalnych 31:52-57 (in Polish)

Morris PJ, Waddington JM, Benscoter BW, Turetsky MR (2011) Conceptual frameworks in peatland ecohydrology: looking beyond the two-layered (acrotelm-catotelm) model. Ecohydrology 4:1-11

Myślińska E (2001) Grunty organiczne i laboratoryjne metody ich badania. PWN, Warszawa (in Polish)

Myślińska E (2003) Development of mucks from the weathering of peats: its importance as isolation barrier. Bull Eng Geol Environ 62:389392

Norrstrom AC (1995) Concentration and chemical species of iron in soils from groundwater/surface water ecotones. Hydrol Sci J 40:319-329

Okruszko H (1976a) Zasady rozpoznawania i podziału gleb hydrogenicznych z punktu widzenia melioracyjnego. Biblioteka Wiadomości IMUZ 52, Warszawa. (in Polish)

Okruszko H (1976b) W pływ melioracji wodnych na gleby organiczne w warunkach Polski. Zeszyty Probl Post Nauk Rol 177:159-204 (in Polish)

Ott F, Kramkowski M, Wulf S, Plessen B, Serb J, Tjallingii R, Schwab M, Słowiński M, Brykała D, Tyszkowski S, Putyrskaya V, Appelt O, Błaszkiewicz M, Brauer A (2017) Site-specific sediment responses to climate change during the last 140 years in three varved lakes in northern Poland. The Holocene 28(3):464-477

Pawluczuk J, Gotkiewicz J (2003) Evaluation of the mineralization process in soils of selected peat ecosystems of North-Eastern Poland in an aspect of soil resources protection. Acta Agrophysica 1(4):721728 (in Polish)

Piaścik H, Gotkiewicz J (2004) Transformation of dewatered peat soils as the cause of their degradation. Roczniki Gleboznawcze, LV, pp $331-338$

Poraj-Górska AI, Żarczyński MJ, Ahrens A, Enters D, Weisbrodt D, Tylmann W (2017) Impact of historical land use changes on lacustrine sedimentation recorded in varved sediments of Lake Jaczno, northeastern Poland. Catena 153:182-193

Puustrjarvi V (1952) The precipitation of iron in peat soils. Helsinki

Ralska-Jasiewiczowa M, van Geel B (1992) Early human disturbance of the natural environment recorded in annually laminated sediments of Lake Gosciaz, central Poland. Veget Hist Archaeobot 1: 33-42.

Raukas A, Tavast E (2002) The Holocene sedimentation history of Lake Võrtsjärv, central Estonia. Geol Q 46:199-206

Reczuga MK, Lamentowicz M, Mulot M, Mitchell EAD, Buttler A, Chojnicki B, Słowiński M, Binet P, Chiapusio G, Gilbert D, Słowińska S, Jassey VEJ (2018) Predator-prey mass ratio drives microbial activity under dry conditions in Sphagnum peatlands. Ecol Evol 8:5752-5764

Reimer PJ, Bard E, Bayliss A, Beck JW, Blackwell PG, Bronk Ramsey C, Buck CE, Cheng H, Edwards RL, Friedrich M, Grootes PM, Guilderson TP, Haflidason H, Hajdas I, Hatté C, Heaton TJ, Hoffmann DL, Hogg AG, Hughen KA, Kaiser KF, Kromer B, Manning SW, Niu M, Reimer RW, Richards DA, Scott EM, Southon JR, Staff RA, Turney CSM, van der Plicht J (2013) Intcal13 and Marine13 radiocarbon age calibration curves 0-50, 000 years Cal Bp. Radiocarbon 55: 1869-1887. 
Renger M, Wessolek G, Schwärzel K, Sauerbrey R, Siewert C (2002) Aspect of peat conservation and water management. J Plant Nutr Soil Sci 165:487-493

Roman M (2011) Objaśnienia do Szczegółowej Mapy Geologicznej Polski 1:50 000, ark. Gostynin, Państwowy Instytut Geologiczny. (in Polish)

Rydin H, Jeglum JK (2006) The biology of peatlands. Oxford Univ. Press, Oxford

Samson M, Słowińska S, Słowiński M, Lamentowicz M, Barabach J, Harenda K, Zielińska M, Robroek BJM, Jassey VEJ, Buttler A, Chojnicki BH (2018) The impact of experimental temperature and water level manipulation on carbon dioxide release in a poor fen in Northern Poland. Wetlands 38:551-563

Sapek B, Sapek A (1987) Changes in the properties of humus substances and the sorption complex in reclaimed peat soils. Int Peat J 2:99-117

Scheffer M (2004) Ecology of shallow lakes. Chapman and Hall, London

Shotyk W, Weiss D, Appleby PG (1998) History of atmospheric lead deposition since 12,370 14C yr BP from a peat bog, Jura Mountains, Switzerland. Science 28:1635-1640

Skowron R, Jaworski T (2017) Changes in lake area as a consequence of plant overgrowth in the South Baltic Lakelands (Northern Poland). Bull Geogr Phys Geogr Ser 12:19-30

Słowińska S, Słowiński M, Lamentowicz M (2010) Relationships between Local Climate and Hydrology in Sphagnum Mire: Implications for Palaeohydrological Studies and Ecosystem Management. Pol J Environ Stud 19:779-787

Słowiński M, Lamentowicz M, Łuców D, Barabach J, Brykała D, Tyszkowski S, Pieńczewska A, Śnieszko Z, Dietze E, Jażdżewski K, Obremska M, Ott F, Brauer A, Marcisz K (2019) Paleoecological and historical data as an important tool in ecosystem management. J Environ Manag 236:755-768

Smith LC, Sheng Y, MacDonald GM, Hinzman LD (2005) Disappearing Arctic lakes. Science 308:1429
Strack M (2008) Peatlands and climate change. IPS, International Peat Society

Succow M, Joosten H (2001) Landschaftsökologische Moorkunde, Stuttgart

Szwed M (2015) The elements of water balance in the changing climate in Poland. Adv Meteorol 149674:13

Szwed M, Karg G, Pińskwar I, Radziejewski M, Graczyk D, Kędziora A, Kundzewicz ZW (2010) Climate change and its effect on agriculture, water resources and human health sectors in Poland. Nat Hazards Earth Syst Sci 10:1725-1737

Tobolski K (1998) Paleoekologiczne studium późnoglacjalnych osadów jeziora Lednica w Imiołkach. Homini. (in Polish)

Tobolski K (2000) Przewodnik do oznaczania torfów i osadów jeziornych, Vademecum Geobotanicum. Wydawnictwo Naukowe PWN, Warszawa, 508. (in Polish)

Van Reeuwijk LP (2002) Procedures for soil analysis. ISRIC, FAO Wageningen

Ventelä AM, Amsinck SL, Kauppila T, Johansson LS, Jeppesen E, Kirkkala T, Søndergaard M, Weckström J, Sarvala J (2015) Ecosystem change in the large and shallow Lake Säkylän Pyhäjärvi, Finland, during the past $\sim 400$ years: implications for management. Hydrobiologia 778:273-294

Więckowski K (1993) The up-to-date state of recognition of bottom sediments in the "Na Jazach" lakes according to their macroscopic features, Lake Gościąż - progress of studies on the sediments and recent environment. Pol Bot Stud, Guidebook Series, pp 77-92

Wyrwicki R (2001) Holocene carbonate sediments: properties and chemistry of gel, composition of liquid and solid components. Prz Geol 49:525-532

Publisher's note Springer Nature remains neutral with regard to jurisdictional claims in published maps and institutional affiliations. 